\title{
A EDUCAÇÃO DE JOVENS E ADULTOS (EJA): UMA FERRAMENTA DE DEMOCRATIZAÇÃO DO ENSINO NO ESTADO DE RORAIMA
}

\section{ARTIGO ORIGINAL}

ANDRADE, Gibton Pereira de ${ }^{1}$

ANDRADE, Gibton Pereira de. A Educação De Jovens E Adultos (EJA): Uma Ferramenta De Democratização Do Ensino No Estado De Roraima. Revista Científica Multidisciplinar Núcleo do Conhecimento. Ano 06, Ed. 06, Vol. 16, pp. 141 176. Junho de 2021. ISSN: 2448-0959, Link de acesso: https://www.nucleodoconhecimento.com.br/educacao/ensino-no-estado, DOI: 10.32749/nucleodoconhecimento.com.br/educacao/ensino-no-estado

\section{RESUMO}

O estudo tem como objeto de pesquisa a Educação de Jovens e Adultos (EJA), analisada sob o prisma de modalidade garantidora do acesso à educação básica gratuita aos que dela não tiveram acesso na idade própria e de forma adequada às condições do educando. Tratada desta forma, a EJA incorpora o direito subjetivo à educação, consoante ao que determina a Carta Cidadã de 1988. O cerne do problema científico procura saber os aspectos jurídicos-educacionais que reconhecem a EJA como exercício da cidadania, considerando as legislações aplicáveis, características específicas do público-alvo e materiais didáticos destinados à modalidade, além dos

\footnotetext{
${ }^{1}$ Mestrando em Direito, Área de Concentração: Direito Internacional, do Programa de Pós-Graduação Stricto Sensu em Direito, da Universidade Católica de Santos/SP UniSantos; possui Pós-Graduação Lato Sensu em Direito Militar, pela Faculdade Verbo Educacional (VERBO JURÍDICO); em Direito Penal e Processual Penal, pela Universidade Estácio de Sá - UNESA; em Direito Público: Constitucional, Administrativo e Tributário, e Bacharelado em Direito pelo Centro Universitário Estácio da Amazônia; Bacharelado em Teologia, pela Faculdade de Ciências, Educação e Teologia do Norte do Brasil - FACETEN; Licenciatura em História; Ciências Humanas; e Letras - Língua Portuguesa; Tecnologia em Gestão Pública; e, Tecnologia em Investigação Forense e Perícia Criminal, todas pelo Centro Universitário Estácio de Ribeirão Preto/SP.
}

RC: 89981

Disponível em: https://www.nucleodoconhecimento.com.br/educacao/ensino-noestado 
fatores determinantes na conquista do curso superior pelo egresso. Através do método hipotético - dedutivo, aliado à técnica exploratória bibliográfica e documental, consubstanciado na construção normativa, entre livros, artigos, dissertações e teses, além de documentos que versam sobre a temática da inclusão, busca-se analisar os aspectos preponderantemente jurídicos da Educação de Jovens e Adultos como ferramenta de democratização do ensino; além disso, diagnosticar o perfil educacional da EJA e suas peculiaridades, com destaque para a legislação, alunado, e materiais didáticos; e, ainda, saber se a Educação de Jovens e Adultos favorece ou prejudica o acesso ao ensino superior, quando comparado o ex-aluno da EJA com o do ensino regular. Neste viés, como instrumento de pesquisa, a entrevista foi a ferramenta de coleta de dados, propondo-se a quantificar as estatísticas de ex-alunos da EJA formados em nível superior e cursos de pós-graduação Lato Sensu e Stricto Sensu, com recorte no Estado de Roraima. Dos resultados alcançados, não obstante às dificuldades, quantificou-se nos recortes estatísticos para o fato de concluir o ensino médio na modalidade EJA não impedir ou diminuir as possibilidades de o egresso cursar uma faculdade, ao contrário, somam-se às intempéries, o fator resiliência, encontrado na quase totalidade dos entrevistados. In fine, a trajetória acadêmica e profissional do pesquisador corrobora e dá luz ao sermão ao firmar convencimento de que todo esforço tem sua recompensa e que o ser humano é dotado da capacidade de se reerguer, deixando o exemplo de resiliência, esperança e positividade.

Palavras-chave: EJA, Democratização, Exercício da Cidadania, Resiliência.

\section{INTRODUÇÃO}

Cursar uma faculdade está nos planos de praticamente a totalidade das pessoas no contexto contemporâneo. Em face da consecução de projetos pessoais e profissionais, concluir os estudos é fundamental e, nesse sentido, desde a mais tenra idade os pais, a escola e amigos já provocam nas crianças o manifesto consoante a pergunta: O que você vai ser quando crescer? À bem da verdade, a resposta para 
esta pergunta entra na seara dos debates sobre a conclusão da educação básica e acesso ao ensino superior.

Contudo, considerando o contexto econômico das pessoas, a isonomia não é alcançada no compartilhamento das oportunidades de acesso à educação básica, considerando índices de permanência na escola e conclusão dos estudos em nível de educação básica no prazo correto. Sobre essa premissa, consideram-se as múltiplas circunstâncias que marcam a vida daquele que desde cedo necessita decidir sobre estudar ou trabalhar para garantir a subsistência. Diante de tais opções, a evasão escolar é característica intrínseca à educação brasileira.

Neste viés, apresenta-se como escopo da presente pesquisa a Educação de Jovens e Adultos (EJA) como ferramenta de democratização do ensino, mormente analisada sob o prisma de modalidade garantidora do acesso à educação básica gratuita aos que dela não tiveram acesso na idade própria, de forma adequada às condições do educando e compreendida como direito subjetivo à educação, conforme determina a Constituição da República Federativa do Brasil de 1988.

A relevância do presente artigo se justifica na investigação dos motivos que induzem ao (des)interesse na continuidade dos estudos, especialmente cursos superiores, considerando que a conclusão do ensino básico via EJA não se configura impossibilidade de acesso à educação superior. Assim, urge definir os motivos que cercam o aluno concludente do Ensino Médio pela EJA a prosseguir ou não nos estudos, especificamente no ensino superior.

Aplicou-se o método hipotético-dedutivo, aliado à técnica exploratória bibliográfica e documental, busca-se demonstrar os aspectos jurídicos-educacionais que delimitam a EJA como exercício da cidadania, ao fomentar o acesso e a permanência do jovem e do adulto na escola, considerando para isso as legislações aplicáveis, características específicas do público-alvo e materiais didáticos destinados à modalidade de ensino, além dos fatores de influência na conquista do curso superior pelo seu alunado.

RC: 89981

Disponível em: https://www.nucleodoconhecimento.com.br/educacao/ensino-no$\underline{\text { estado }}$ 
Com vistas a firmar convencimento da real possibilidade de conquista do curso superior por ex-alunos, quantificaram-se as estatísticas de egressos da EJA, atualmente formados em nível superior e cursos de pós-graduação Lato Sensu e Stricto Sensu, com recorte para o Estado de Roraima; e, in fine, propõe-se o relato da trajetória acadêmica e profissional de ex-aluno da EJA aprovado em concurso público e que, atualmente com graduações e especializações, foi aprovado em 1 - lugar no Processo Seletivo Discente para o ingresso em Programa de Pós-Graduação Stricto Sensu em Direito de umas das Universidades mais conceituadas do Brasil, deixando o exemplo de resiliência, esperança e positividade.

\section{PERCURSO METODOLÓGICO}

A metodologia proposta para a realização da pesquisa constitui-se no método hipotético-dedutivo, a partir de pesquisa documental e de revisão bibliográfica. Os procedimentos técnicos estão diretamente ligados à pesquisa bibliográfica, documental, e estudo do caso concreto.

Quanto à natureza, a pesquisa é aplicada, com abordagem quantitativa do problema e seus objetivos exploratórios, de proposta específica, permitindo-se os embasamentos teóricos das obras educacionais, normativas jurídicas, artigos e legislações que versam sobre a inclusão na educação, com elementos que corroboram a importância do exercício da cidadania. Das etapas da pesquisa, partiuse da exploração do problema, envolvendo o levantamento bibliográfico, via diálogo dos autores; posteriormente, buscam-se no desenvolvimento da pesquisa as respostas às questões norteadoras, objetivando o claro entendimento sobre o tema proposto.

A pesquisa propôs um espaço para entrevistas com alunos(as) que concluíram o Ensino Médio via Educação de Jovens e Adultos, objeto desta pesquisa. No decurso do processo metodológico, buscou-se colecionar dados de ingresso no Ensino Superior, de egressos do EJA, bem como expectativa daqueles que ainda não 
ingressaram em Faculdades, especialmente aos que participarem da pesquisa. Quantos aos instrumentos da pesquisa, compôs-se de entrevista com alunos e exalunos do EJA, no total de 30 (trinta) voluntários, com público-alvo e recorte da pesquisa para alunos com idade entre 18 e 40 anos; alunos que exercem atividade profissional; e, alunos que pretendem prestar o vestibular.

Da coleta e análise dos dados de ex-alunos da Educação de Jovens e Adultos, vislumbram-se estatísticas reveladoras, sobretudo considerando o exposto na presente pesquisa, no que concerne ao contexto da Educação de Jovens e Adultos, o perfil do alunado desta modalidade, em face dos fatores que cercam o dia a dia do trabalhador estudante. Em análise final, os resultados demonstram a existência de fatores presentes nas decisões do público-alvo da pesquisa que se traduz na força motriz que os une, claramente evidenciado nas respostas de quase a totalidade das perguntas feitas aos entrevistados, a motivação. Os Resultados encontram devidamente citados no corpo do texto e ao final, no Apêndice A - Entrevista.

\section{DESENVOLVIMENTO}

\subsection{A EDUCAÇÃO DE JOVENS E ADULTOS NO BRASIL E A DEMOCRATIZAÇÃO DO ENSINO}

Do nascimento às fases finais da vida, passamos por várias etapas de aprendizado. Algumas são inatas ao ser, outras precisam ser adquiridas e, neste sentido, a educação ocupa lugar de destaque na formação das pessoas. Diante disso, o processo educacional está intrinsecamente ligado ao comportamento humano, uma vez que somente o ser humano é capaz de aprender e ensinar por meio das relações interpessoais e as de ordem sociais, econômicas, políticas e culturais.

Com efeito, a Carta Cidadã de 1988, nossa Constituição Federal, no viés social, tratou a educação como direito subjetivo aos cidadãos brasileiros, além dos estrangeiros 
residentes em território nacional, de modo a garantir o acesso à educação básica de forma pública, ofertada pelo próprio Estado.

Não obstante, por razões diversas, as oportunidades de aprendizado não são universais, considerando índices de permanência na escola e conclusão dos estudos em nível de educação básica no prazo correto. Por questões de subsistência, muitos não vêm alternativas outras que não seja o abandono escolar. Para outros, os fatores de desistência estão relacionados aos problemas familiares, sociais e/ou escolares. Certo é que, não de hoje, a educação pública brasileira é marcada pela evasão escolar.

Registre-se, no viés dessa temática, que a evasão escolar ocupa lugar proeminente nos debates sobre a educação pública brasileira. Ademais, soma-se às discussões, 0 fato de que desde o nascedouro da nação brasileira, a educação era destinada à classe dominante, desfavorecendo desde o início os menos afortunados.

Em que pese citar, as palavras de Beleza e Nogueira (2020, p. 98) dão conta que "desde o início do programa colonial brasileiro, a educação nunca teve como alvo a classe baixa (os pobres), mas sempre serviu à classe dominante. Diante disso, muitas crianças e jovens não tinham oportunidades de educação básica". Da assertiva, à exemplo de outros direitos, como o voto que era censitário, ou seja, com base na renda, depreende-se que a educação no Brasil serviu (de início) àqueles que detinham o poder econômico, deixando em situação de exclusão de oportunidades os mais singelos.

Contudo, com viés de democratizar o acesso à educação básica às mais diversas classes sociais, surge no cenário da educação brasileira a Educação de Jovens e Adultos (EJA), presente em seu início no contexto da educação popular. Mas, convenha-se, em se tratando de pessoas em idade adulta, especialmente os trabalhadores, "as escolas noturnas (...) foram a única forma de educação de adultos praticada no país" (PAIVA, 2003, p. 56, 57). 
Diante disso, oportuno clarear e corrigir o equívoco de atrelar o conceito de EJA ao estudo noturno, longe disso, já que se define pela especificidade do público-alvo. Em síntese, recuperar o "tempo perdido" não se resume como papel principal da EJA, traduz-se pela libertação pessoal, transposição das limitações do analfabetismo, de forma a promover a satisfação pessoal e renovação da esperança da realização dos sonhos, projetos e metas.

\subsubsection{SURGIMENTO, EVOLUÇÕES E FORMATO ATUAL DA EDUCAÇÃO DE JOVENS E ADULTOS NO BRASIL}

O país tem sido assolado por altas taxas de analfabetismo e/ou semianalfabetismo há muito tempo. Contudo, ao longo do tempo, não foram poucos os programas criados no objetivo de reduzir esse estigma, figurando entre os programas educacionais a EJA.

Cardoso e Passos (2016) relatam que o problema do analfabetismo começou durante o período colonial, perdurando por quatro séculos. Nesse contexto, os alunos não acessavam a escola, sequer sabiam ler e escrever e, em consequência, a alfabetização era via oralidade. As escolas somente surgiram a partir do esforço dos jesuítas, atrelado ao objetivo da formação religiosa, quais eram organizadas para os filhos de colonos e crianças indígenas. Assim,

Foi a educação dada pelos jesuítas que transformou em educação popular, suas características evidenciavam a aristocracia rural brasileira, que se estendeu por todo o período colonial e por todo o império, e entrou no período da república sem sofrimento. Ainda que o atraso da educação na sociedade comece a aumentar, alcance o estrato inferior da população e obrigue a sociedade a ampliar a oferta de escolas, a estrutura final mudará (MOURA, 2003, p. 29).

Perceptível que a EJA envolveu em suas linhas mestras não apenas a educação escolar formal, mas de igual forma ocorreu na informalidade, cumprindo seu papel com multiformas de transmitir conhecimento, entre os meios, as associações de moradores, sindicatos e comunidades, centros religiosos etc., oportunizando o acesso

RC: 89981

Disponível em: https://www.nucleodoconhecimento.com.br/educacao/ensino-noestado 
ao conhecimento, ainda que limitado ao básico. Nesse contexto, Vieira (2009) ressalta que essa educação ainda foi por muito tempo menosprezada até ser legalizada no Brasil.

Com a chegada da Era Vargas (1930), instituiu-se a política baseada na exportação de café. À época, o analfabeto adulto era visto como "sem futuro" e não tendo oportunidade de aprender a ler e escrever, restou-lhe o trabalho no campo. Fomentando o acesso à educação básica, Getúlio instituiu a "ditadura da cidadania", com foco na educação de crianças e jovens, posteriormente considerada a educação de adultos.

Vieira (2009) destaca que por volta do século XX foram aprovados projetos de leis que destacaram a obrigação da educação de jovens e adultos com fins de aumentar o número de eleitores, que se traduziu na satisfação dos interesses da elite, já que vigorava a Lei Saraiva de 1882 - (Decreto o 3 029, de 9 de janeiro de 1881) - qual legislou no sentido de impossibilitar o voto de analfabetos, tornando alistáveis somente os que sabiam ler e escrever.

Verifica-se ainda, por Mészáros (2008), que posterior a 2ª Guerra Mundial aflorou um período em que o governo federal fez campanhas nacionais de alfabetização voltadas aos analfabetos, objetivando atender principalmente a população rural., ofertando a EJA no primário, vindo o ginásio a partir da década de 1960 (BELEZA; NOGUEIRA, 2020).

Dos programas educacionais do período está o Movimento Brasileiro de Alfabetização (MOBRAL), qual limitava-se à "alfabetização funcional". Este, declinou em face da Lei de Diretrizes e Bases da Educação (LDB 5692/71), que implementou o Supletivo Projeto Logos I e II, onde, à época, o aluno estudava em casa via cartilhas e comparecia na sede dos colégios supletivos para as avaliações. Destacando o Mobral, Mota $(2009$, p.15) traz à baila as muitas críticas ao Movimento Brasileiro de Alfabetização, em razão de que:

RC: 89981

Disponível em: https://www.nucleodoconhecimento.com.br/educacao/ensino-no$\underline{\text { estado }}$ 
Em 1967, qualquer pessoa podia ter aulas do programa, e o MOBRAL também foi alvo de críticas por não garantir a durabilidade do aprendizado e o aluno esquecer facilmente de ler e escrever. Portanto, o trabalho docente do MOBRAL não é crítico e problemático, e sua orientação, supervisão e produção de material são centralizadas. Portanto, o programa cria analfabetos alfabetizados, pessoas que muitas vezes aprendem a assinar apenas o próprio nome e não podem participar de atividades de alfabetização no meio social em que vivem.

Avançando no tempo, contemporâneo ao período de inovação da educação nacional (década de 1960), os conceitos de educação na visão de Paulo Freire começaram a ser difundidos enfaticamente na educação brasileira. Conhecido por aludir ao método para os menos favorecidos, o educador buscou homogeneizar a prática e a realidade dos alunos.

Moura (2003, p. 124) destaca que Paulo Freire redefiniu a abordagem na alfabetização de adultos, combinando a leitura e escrita, conhecimento e expressão cultural, compreensão e interpretação de problemas reais no Brasil. Acredita que "a educação é essencial para a compreensão das humanidades da sociedade".

No viés do educador, o conhecimento relaciona-se à realidade específica do aluno, ao passo que o educar visa discutir a realidade com os indivíduos, visando mudança e superação. Com efeito, professor e aluno valorizam e constroem conhecimentos por meio do diálogo. Não obstante, "para ser válida, toda educação, toda ação educativa deve necessariamente estar precedida de uma reflexão sobre o homem e de uma análise do meio de vida concreto do homem concreto a quem queremos educar". (FREIRE, 1979, p. 19).

Com o processo de redemocratização da República, iniciado em 1985, Mota (2009) relata que o governo federal encerrou o MOBRAL, abrindo alas à Fundação EDUCAR (Fundação Nacional de Educação de Jovens e Adultos). Esclarece ainda que a fundação era responsável pelas ofertas públicas gratuitas e educação básica de qualidade para jovens e adultos. Destaca-se, no período, a descentralização de recursos, cabendo ao governo federal o investimento na EJA e aos Estados e Municípios a responsabilidade de educar a população.

RC: 89981

Disponível em: https://www.nucleodoconhecimento.com.br/educacao/ensino-no$\underline{\text { estado }}$ 
Porém, no Governo de Collor, a Fundação EDUCAR foi "exterminada" e não se garantiu outro plano/programa com iguais funções. Contudo, em 1996 foi promulgada a nova "Diretiva Nacional da Educação e Lei Básica" - (Lei nº 9.394/1996 - Estabelece as diretrizes e bases da educação nacional). Destarte, a EJA estabeleceu-se como educação básica em nível fundamental e médio.

$\mathrm{Na}$ década de 2000, discussões em torno das experiências da educação de jovens e adultos ganharam destaque com o Guia Nacional de Currículo Educacional para Jovens e Adultos - Diretrizes Curriculares Nacionais para a Educação de Jovens e Adultos - compilado pela Comissão Nacional de Educação/Câmara de Educação Básica, de 10 de maio de 2000, no Parecer CNE/CEB 11/2000, relacionado ao

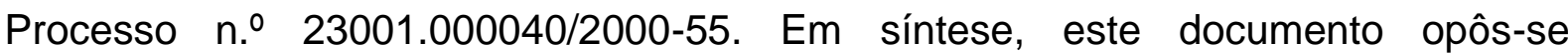
frontalmente à discriminação dos pseudo-alfabetizados.

Em seu teor, o parecer explica detalhes sobre tempo e espaço entre jovens e adultos; discussão sobre o conteúdo do curso; compreensão da importância das faixas etárias (jovens e adultos) neste tipo de ensino; e formulação de cursos regulares noturnos, além do Plano de Ensino (EJA). O caderno de Diretrizes é enfático ao asseverar ser a EJA é um direito, sobre o qual apresenta o conceito de "compensação", substituído por "compensação e justiça".

Atualmente, ao pensar o formato adequado para a Educação de Jovens e Adultos (EJA), presencia-se um crescimento e fortalecimento contínuo da modalidade em todo o país, com avanços consideráveis no enfoque humano, condições sociais e contextualização histórica. A dignidade da pessoa humana destaca-se e se mostra relevante, quando se consideram as possibilidades, traduzindo-se pela passada certa na direção da conquista, livrando-se da visão simplificada da educação.

Em síntese, precisa-se compreender o significado das conquistas e dos direitos constitucionais e civis estabelecidos na legislação vigente, que dão sustentação a EJA, a exemplo da Lei 9.394/96, qual enfatiza a autonomia, flexibilidade e liberdade no compromisso de escolas e educadores para um ensino de qualidade.

RC: 89981

Disponível em: https://www.nucleodoconhecimento.com.br/educacao/ensino-noestado 


\subsubsection{A EDUCAÇÃO DE JOVENS E ADULTOS NO VIÉS DA DEMOCRATIZAÇÃO DO ENSINO}

Consubstanciadas no Estado Democrático de Direito ( $\mathrm{CF} / 88$ ), algumas considerações são necessárias e aplicáveis à educação de jovens e adultos, as quais sedimentam as hipóteses à problemática desenvolvida na pesquisa. A Carta Cidadã de 1988, no preâmbulo, destaca que a democracia estabelecida se destina a "assegurar o exercício dos direitos sociais e individuais, a liberdade, a segurança, o bem-estar, o desenvolvimento, a igualdade e a justiça como valores supremos de uma sociedade fraterna, pluralista e sem preconceitos".

Quando se recorta do texto palavras como "direitos sociais" e "igualdade e justiça", estamos diante do perfeito propósito do legislador em possibilitar o equilíbrio da balança da justiça e equidade. Nesse sentido, fundamentos como "cidadania" e "dignidade da pessoa humana" (Art. $1^{\circ}$, Inc. II e III, da CF/88), são aplicáveis e carecem de atenção do Estado em suas políticas públicas destinadas a EJA, considerando o contexto do público-alvo desta modalidade, já sabido que não foi o foco da educação tradicional por séculos e décadas

É por dever de justiça considerar na presente discussão a previsão do Art. $3^{\circ}$, Inc. I, III e IV, da $\mathrm{CF} / 88$, dispositivos legais que refletem os objetivos fundamentais da República, dentre outros, cite-se: a "construção da sociedade livre, justa e solidária"; a "redução das desigualdades sociais e regionais", além da "promoção do bem igualitário, sem preconceitos e quaisquer outras formas de discriminação".

Neste viés constitucional, o Art. 205, da Constituição Federal de 1988 estabeleceu que "a educação, direito de todos e dever do Estado e da família, será promovida e incentivada com a colaboração da sociedade, visando ao pleno desenvolvimento da pessoa, seu preparo para o exercício da cidadania e sua qualificação para o trabalho". Cite-se ainda o Inc. I, do Art. 206 da CF/88, no qual aprendemos que o ensino 
obedecerá ao princípio da "igualdade de condições para o acesso e permanência na escola".

Extrai-se, do contexto da Carta Cidadã, que o foco da democratização da educação é - da ampliação dos horizontes do público excluído do tradicional processo educacional. Não se pode olvidar a seriedade do Conselho Nacional de Educação/Câmara de Educação Básica ao tratar do tema da democratização do acesso à educação básica, momento da aprovação do Parecer CNE/CEB 11/2000 Processo n. $.23001 .000040 / 2000-55$, combatendo de forma clara e objetiva a discriminação contra àqueles que compõe a fatia dos excluídos, conforme se verifica no Voto do Relator:

Os Estados - Partes do presente Pacto reconhecem que, com o objetivo de assegurar o pleno exercício desse direito: a educação primária deverá ser obrigatória e acessível gratuitamente a todos; a educação secundária em suas diferentes formas, inclusive a educação secundária técnica e profissional, deverá ser generalizada e tornar-se acessível a todos, por todos os meios apropriados e, principalmente, pela implementação progressiva do ensino gratuito; (...); dever-se-á fomentar e intensificar na medida do possível, a educação de base para aquelas pessoas que não receberam educação primária ou não concluíram o ciclo completo da educação primária. (Art.13,1, "d", do Pacto Internacional sobre Direitos Econômicos, Sociais e Culturais da Assembleia Geral da ONU de 16.12.66, aprovado, no Brasil, pelo decreto legislativo №. 226 de 12.12 .95 e promulgado pelo decreto $\mathrm{n}^{\circ}$. 591 de 7.7.92).

Diante das assertivas, verifica-se que os valores educacionais da Educação de Jovens e Adultos, consoante ao texto constitucional, servem de balizadores nas ações próeducacionais voltadas a corrigir os erros e falhas do passado, bem como condicionam os passos para o futuro melhor para jovens e adultos.

\subsubsection{DIREITO EDUCACIONAL: DISPOSITIVOS LEGAIS APLICÁVEIS À EDUCAÇÃO NO BRASIL}

Via de regra, nas nações desenvolvidas, a educação ocupa lugar proeminente e, nesse sentido, não pode ser diferente em solo pátrio, a educação precisa ser

RC: 89981

Disponível em: https://www.nucleodoconhecimento.com.br/educacao/ensino-noestado 
prioridade. Não é coincidência que termos como globalização, desenvolvimento econômico e sustentável, capitalismo e revolução tecnológica, direito e cidadania, entre outros, passam pelo processo educacional de qualidade.

Neste viés, notória é a relação entre direito, educação e dignidade humana. No campo internacional, declarações de direitos dão ênfase à educação no contexto da dignidade. A exemplo, cite-se a "Declaração Americana dos Direitos e Deveres do Homem" (1948) e o "Pacto Internacional sobre Direitos Econômicos, Sociais e Culturais" (1966), incorporado ao ordenamento jurídico brasileiro via Decreto $\mathrm{n} . .591$, de 6 de julho de 1992.

Extraído da Declaração e subsidiariamente do Pacto Internacional, o direito aplicado caminha no sentido de que toda pessoa deve ter acesso à educação e, por esta, seja proporcionado o direito de preparação para sobrevivência digna. Além de ligar-se à dignidade humana, a educação é considerada um conceito de direitos básicos, nos padrões formais. Cardoso e Passos (2016) firmam esses direitos ao imperializa lós, conforme ordem constitucional, podendo ser exigidos e acionados via "Império da Lei".

Beleza (2020) afirma que os direitos sociais, econômicos e culturais correspondem a esse aspecto, exigindo do poder público uma atuação positiva, no sentido de melhores condições de vida e dignidade humana, além da redução da desigualdade social. A doutrina jurídica, além do texto constitucional, argumenta que existem cinco direitos humanos, entre os mais básicos: vida, liberdade, igualdade, segurança e propriedade. Machado (2002) leciona que o universo dos direitos está diretamente relacionado a um dos cinco direitos básicos contidos no caput Art. 5ำ da Constituição Federal de 1988.

Dado a teoria, Moura (2003) afirma ser inequívoco considerar o direito à educação como garantia fundamental. Conforme ensina, o direito à educação está direta e internamente conectado à igualdade e liberdade. O direito a ser educado é tão importante na Constituição Cidadã que Lehenbauer e Scheibel (2010) entendem ser o caráter abrangente a toda educação e pontuam claramente que a fundamentalidade

RC: 89981

Disponível em: https://www.nucleodoconhecimento.com.br/educacao/ensino-no$\underline{\text { estado }}$ 
do direito à educação é inerente ao caráter de essencialidade ao pleno desenvolvimento da personalidade e concretização da cidadania.

No teor da Carta Cidadã de 1988 (Art. 205), a educação é tida como direito de todos, com características de universalidade, gratuidade, democracia, de viés comunitário e padrão qualitativo e, "pari passu" - simultaneamente - a legislação infraconstitucional complementa a instrumentalidade normativa, com fins de alcance do direito público subjetivo de todos os brasileiros.

Há de se registrar que, não sendo aplicado de fato, não adiantará possuir todo o acervo jurídico de sustentabilidade. É necessário a efetivação e concretude pelo Executivo, com fiscalização do Legislativo e, se necessário, a intervenção do Judiciário, de modo a "tirar do papel" a teoria e verdadeiramente se "dê forma" aos direitos na educação.

\subsubsection{LEI DE DIRETRIZES E BASES DA EDUCAÇÃO NACIONAL E SUA APLICABILIDADE À EDUCAÇÃO DE JOVENS E ADULTOS}

Em que citar os dispositivos constitucionais que versam sobre educação, incumbe pontuar na Lei de Diretrizes e Bases da Educação Nacional (LDB) os que tratam da "Educação de Jovens e Adultos", inicialmente tratada no Art. $4^{\circ}$, Inc. I e VII, que asseveram o "dever do Estado como a educação escolar pública" e sua efetivação mediante políticas que garantam o "I - Ensino fundamental, obrigatório e gratuito, inclusive para os que a ele não tiveram acesso na idade própria". Igualmente, no bojo do diploma legal, a observância da "VII - oferta de educação escolar regular para jovens e adultos, com características e modalidades adequadas às suas necessidades e disponibilidades".

Não obstante, destaca-se no mesmo dispositivo, a dever de oferta que garanta àqueles que forem trabalhadores "as condições de acesso e permanência na escola", ou seja, fomento a não evasão escolar, considerando as peculiaridades da 
modalidade e não análise genérica e superficial, diferindo-se do ensino regular. Com isso, abre-se espaço para um novo conceito de formação de jovens e adultos.

Consoante ao exposto, o Art. $5^{\circ}$, §1, da LDB, reforça que "compete aos Estados e aos Município, em regime de colaboração, e com a assistência da União: I - recensear a população em idade escolar para o ensino fundamental, e os jovens e adultos que a ele não tiveram acesso. Na lei, está claro e evidenciado que o público de jovens e adultos é considerado em situação especial e sempre que a lei trata do tema, o faz com seus adjetivos, ou seja, àqueles que "não tiveram acesso" na idade ou no tempo correto e, frisando a tentativa de reorientação e salvaguarda dos interesses deste público específico.

A educação de jovens e adultos é tema recorrente da LDB, no Art. 37, e §§, enfatizando a gratuidade do ensino "aos jovens e aos adultos que não puderam efetuar os estudos na idade regular", além disso, que a oferta seja feita com "oportunidades educacionais apropriadas, consideradas as características do alunado, seus interesses, condições de vida e de trabalho, mediante cursos e exames". Neste sentido, registre-se que "o poder público viabilizará e estimulará o acesso e a permanência do trabalhador na escola, mediante ações integradas e complementares entre si".

Percebe-se claramente a intensão legislativa no fomentar a EJA, ao destacar as características peculiares, garantia do direito ao ensino, considerando os interesses, condições de vida e trabalho, apropriadas oportunidades e entre outras ações que integradas e complementares entre si viabilizarão o acesso e a permanência do trabalhador na escola, visto na ótica da garantia de um direito social subjetivo, ou seja, a democratização do ensino.

\subsubsection{ASPECTOS JURÍDICOS-EDUCACIONAIS E POLÍTICO- SOCIAIS DA EJA}

RC: 89981

Disponível em: https://www.nucleodoconhecimento.com.br/educacao/ensino-no$\underline{\text { estado }}$ 
Ao tratar de educação básica, o Art. 208 da CF/88 estipula as obrigações educacionais do estado, as quais serão efetivadas observando sua obrigatoriedade e gratuidade, "assegurada inclusive sua oferta gratuita para todos os que a ela não tiveram acesso na idade própria" e ainda a "oferta de ensino noturno regular, adequado às condições do educando".

Registre-se o enfoque constitucional na questão da inclusão social, considerando sempre as condições e peculiaridades do público-alvo. Em síntese, a questão social deve ter atenção redobrada do poder público, traduzindo-se por um "dever-ser" objetivo, em que pese citar, a "obrigação de fazer" do Estado, manifesto nas políticas públicas de inserção social.

Neste sentido, Aranha (2001) comenta que a transformação do viés educacional de burocrática para progressista, de democrática conservadora e neoconservadora para liberadora, voltando-se para temas importantes para o alunado. Assim, visa contribuir na superação e libertação da dominação cultural, política, ideológica e econômica. Neste viés, a EJA deve ser libertadora.

Com isso, não se escanteia o valor das pessoas ao redor, ao contrário, os alunos são detentores de direitos previstos na LDB (1996) que, aliás, já registra desde o seu Art. $1^{\circ}$ que "a educação abrange os processos formativos que se desenvolvem na vida familiar, na convivência humana, no trabalho, nas instituições de ensino e pesquisa, nos movimentos sociais e organizações da sociedade civil e nas manifestações culturais". Portanto, urge-se da sociedade e dos professores fazer valer a previsão legal do Art. 2º da LDB que frisa ser a educação dever da família e Estado, que "inspirada nos princípios de liberdade e nos ideais de solidariedade humana, tem por finalidade o pleno desenvolvimento do educando, seu preparo para o exercício da cidadania e sua qualificação para o trabalho".

A premissa elencada é "não se esquivar da lei". Em todos os níveis, governo e sociedade devem juntar forças e promover a consciência do dever cívico imposto, qual seja, o de ofertar uma educação de qualidade, zelar pelo acesso e permanência na

RC: 89981

Disponível em: https://www.nucleodoconhecimento.com.br/educacao/ensino-noestado 
escola, em face do desenvolvimento intelectual do aluno ser o próprio exercício da cidadania e da consciência dos seus direitos e deveres como cidadão.

\subsection{A EJA FRENTE ÀS PECULIARIDADES DO PÚBLICO-ALVO}

Cabe pontuar que a EJA é uma modalidade ofertada para um público bem específico, como já discutido, por motivos comuns entre si, a exemplo do que trata a LDB, não acessaram a escola no período regular ou na idade correta.

Não obstante, o aluno/EJA deve ser visto inteiramente capaz tanto quanto aquele do ensino regular. Tal capacidade contempla melhores condições de vida e novos horizontes, sempre motivados na busca pela realização e comprometimento com metas pessoais e/ou profissionais. Das muitas peculiaridades, as elencadas a seguir são as que apresentam maior pertinência temática com a proposta da presente pesquisa.

\subsubsection{CARACTERÍSTICAS INTRÍNSECAS DO PÚBLICO-ALVO DA EDUCAÇÃO DE JOVENS E ADULTOS}

Interpretado à luz da LDB, a EJA tem recorte de público com características bem específicas. Destas, a que traduz o diagnóstico do público-alvo da EJA e que se amolda perfeitamente na proposta é a possibilidade de recuperar o tempo perdido.

Esse entendimento extrai-se do Art. $4^{\circ}$, Inc. I, da LDB, que trata da obrigatoriedade e gratuidade do ensino "para os que a ele não tiveram acesso na idade própria" e do Inc. VII, que se reporta aos "jovens e adultos com características e modalidades adequadas às suas necessidades e disponibilidades". Assim, recuperar o tempo perdido é um exercício da cidadania, consoante ao Art. $2^{\circ}$, da LDB qual nos ensina que os fins que justificam a educação servem o pleno desenvolvimento do educando.

Neste viés, o perfil do alunado da EJA é visto sob a ótica da maturidade e peculiaridades culturais, sociais, familiares e profissionais. A consciência da realidade

RC: 89981

Disponível em: https://www.nucleodoconhecimento.com.br/educacao/ensino-no$\underline{\text { estado }}$ 
sem dúvidas traduz-se no resgate do tempo desperdiçado, mas de igual modo, vislumbra-se na expectativa de novas oportunidades, conquistas profissionais e pessoais.

Faz-se necessário diagnosticar o público a que se destina a educação. Neri (2008) aduz ao fato do jovem se motivar pelo futuro e inovações tecnológicas. $O$ adulto prioriza o mercado de trabalho, mas, o idoso vê na oportunidade uma perspectiva de cidadania. Porém, digne-se registrar que a cidadania se destina só ao idoso, mas tanto o jovem quanto ao adulto, o que merece destaque é a conquista do espaço na vida de forma reconhecida (NERI, 2008).

Depreende-se desse contexto que cada aluno deseja ser valorizado e atuante em suas escolhas, atuando de forma crítica e participativa nas decisões. Neste viés, quando a escola favorece, contextualiza-se no dia a dia do aluno na forma de "currículo escolar", fortalecendo o exercício da cidadania nas demais fazes da vida (VIEIRA, 2009).

De forma genérica, outra característica marcante entre alunos da EJA é a classificação na economia de subsistência, forçando as atividades de trabalho em horários diurnos (horário comercial). Além disso, não poucas vezes, meninas que engravidaram de forma precoce (muitas na fase de transição da infância para adolescência). Somam-se ainda os jovens excluídos da escola por motivos diversos e alheios às suas vontades, a exemplo das drogas e criminalidade; e idosos sem oportunidades no período regulamentar.

Em tempos hodiernos, destaca-se na EJA o expressivo número de jovens, segundo estatísticas do Instituto Nacional de Estudos e Pesquisas Educacionais Anísio Teixeira (INEP, 2019). Conforme estatística[2] - "o perfil dos estudantes" - a EJA vem se caracterizando por "alunos com menos de 30 anos representando $62,2 \%$ das matrículas da educação de jovens e adultos. Nesta faixa etária, 57,1\% dos estudantes são do sexo masculino. Quando se observa os estudantes com mais de 30 anos, as mulheres correspondem a 58,6\% das matrículas". Com efeito, a predominância do 
sexo masculino até os 30 anos, relaciona-se ao fato do homem começar a trabalhar mais cedo, contrapartida, as mulheres predominarem após os 30 anos motiva-se em face de grande parte já serem mães, necessitando de formação profissional com vistas ao mercado de trabalho.

Consoante ao exposto, Silva (2015) assevera que a visão de mundo da pessoa adulta que retorna aos estudos após um tempo fora da sala de aula é extremamente peculiar. Em verdade, são protagonistas de histórias reais e pessoas ricas em experiências, configurando-se tipos humanos diversos, com crenças e valores consolidados. Essas características são manifestas recorrentemente entre o público-alvo da Educação de Jovens e Adultos.

\subsubsection{O MATERIAL DIDÁTICO DA EJA NO DESCOMPASSO COM A REALIDADE DO PÚBLICO-ALVO}

Em face de lacunas nos Parâmetros Curriculares Nacionais sobre os aspectos do material ou recurso didático - ainda em conceitos superficiais - procura-se, para o momento, definir os termos em que possa definir o que seja material didático, qual seja, o que Bandeira (2009, pg.14) diz serem os "produtos pedagógicos utilizados na educação e, especificamente, como o material instrucional que se elabora com finalidade didática".

Dado o sentido, está claro que o material didático está intrinsicamente ligado ao "suporte" materializador do conteúdo a ser ministrado, podendo ser estes impressos, recursos de áudio e visuais, e ainda as tecnologias e novas mídias disponíveis no mercado voltado à educação. Neste viés, os materiais e os recursos destinados ao processo de ensino-aprendizagem devem ser atualizados à medida que o tempo e as tecnologias avançam, consoante a fala de Bandeira (2009, p.15), em que "cada época exibe um conjunto de técnicas, do papiro aos meios digitais no século $\mathrm{XXI}$, estas mudanças revolucionaram a escrita, a produção e a difusão do livro", elementos estes que concebem uma evolução didática.

RC: 89981

Disponível em: https://www.nucleodoconhecimento.com.br/educacao/ensino-no$\underline{\text { estado }}$ 
Não obstante às evoluções dos recursos didáticos e dos materiais disponíveis ao processo de ensino-aprendizagem, há uma gritante disparidade no material didático da EJA, percebida principalmente no distanciamento entre o "recorte" dos livros e o público-alvo, quando considerada a bagagem de conhecimento empírico do alunado, não levado em conta.

Freire (1999), aponta que o educador necessita desenhar a partir do seu conhecimento de vida e do conhecimento de vida do educando, do contrário, o educador falha. Contrário sensu, em sua maioria, o que ocorre é o uso dos materiais didáticos produzidos para o universo do 'ensino regular', no intuito de reutilizá-los na EJA.

Assim, enxerga-se a discrepância entre o público-alvo da EJA e o material destinado, totalmente fora do contexto cultural, familiar e profissional dos alunos, em face do material didático ser produzido para outro universo do ensino regular, este com dinâmica diferente do alunado jovem/adulto, o que contribui em muito para o "descompasso didático", ocasionando o consequente desânimo por parte dos alunos de maiores idades. Essa característica negativa piora pari passu - no mesmo passo - quando os docentes aplicam a didática própria do público infantil, não percebendo que o público/auditório é outro.

Em que pese citar, há uma preocupação recorrente do Ministério da Educação em suas legislações, encaixando na proposta o Programa Nacional do Livro Didático, com reflexões sobre a produção do material didático em suas multifaces. Considerando ainda a temática, merece os "manuais com uma leitura e visão conservadoras e fragmentadas para o conteúdo que atualmente temos em um processo progressivo e a substituição por materiais mais consistentes com a realidade da EJA" (MINISTÉRICO DA EDUCAÇÃO - PROGRAMA BRASIL ALFABETIZADO, 2021).

Neste viés, faz-se coro aos materiais didáticos adequados à realidade cultural e mais contemporânea do contexto que cerca a educação de jovens e adultos, considerando as experiências que envolvem o público-alvo da EJA, tornando-se uma prova de RC: 89981

Disponível em: https://www.nucleodoconhecimento.com.br/educacao/ensino-noestado 
cidadania para com os "excluídos" de outrora que necessitam condução da interdisciplinaridade.

Neri (2008), menciona cada vez mais o quadro dos fenômenos que ocorrem fora da escola no escopo de uma única disciplina. Diante disso, a figura professor/pesquisador é de vital importância. Deve-se ter um esforço na pesquisa e elaboração dos materiais didáticos, de forma a ter na interdisciplinaridade e interculturalidade a sua base estabelecida, concorrendo para o aprendizado mais satisfatório no contexto do ensino do jovem/adulto.

\subsection{A EDUCAÇÃO DE JOVENS E ADULTOS (EJA) COMO FATOR PREPONDERANTE NO ACESSO E PERMANÊNCIA NO ENSINO SUPERIOR}

Cursar uma faculdade, indiscutivelmente, está no planejamento humano em contexto contemporâneo. Compreende parte dos sonhos, conquistas de metas pessoais e profissionais e, nesse sentido, desde a mais tenra idade os pais, os amigos e escola já provocam nas crianças a intenção em manifestar-se diante da seguinte pergunta: O que você vai ser quando crescer? A resposta para esta pergunta entra na seara dos debates sobre acesso ao ensino superior.

Conforme a LDB, a Universidade traduz-se exatamente pelo seu significado prático, sendo "instituições pluridisciplinares de formação dos quadros de profissionais de nível superior, de pesquisa, de extensão e de domínio e cultivo do saber humano". Em palavras coloquiais é um universo de mentes e pensamentos em formação, convivendo no tempo e no espaço. Incluído no contexto universitário, Santos (2020) enfatiza que para o aluno iniciante na jornada acadêmica a universidade é vista no espectro de novo mundo no qual se vive, pensa, realiza-se tarefas e interage-se com múltiplas pessoas, entre colegas, professores, administradores etc.

RC: 89981

Disponível em: https://www.nucleodoconhecimento.com.br/educacao/ensino-no$\underline{\text { estado }}$ 
Neste sentido, existem etapas a cumprir na passagem da educação básica para a formação de nível superior, as quais alternam-se de momento a momento e de público para público. No tocante aos oriundos da EJA, as alternâncias evidenciam a complexidade que envolvem o trabalhador, além de características próprias da faixa etária adulta, lista-se entre outras: obrigações como pais e/ou mães; filhos pequenos ou recém-nascidos; residências distantes, moradias em locais interioranos; fora as questões étnicos-raciais; e ainda a classe econômica, chegando por vezes a situaremse abaixo da linha da pobreza.

Percebe-se que para tomarem assentos nos bancos das universidades, os obstáculos se opõem aos desejos de conclusão do curso superior. Sobre isso, Lehenbauer e Scheibel (2010) iluminam o fato de que o ingresso na universidade abrange hábitos e mudanças relacionadas a atividades de saúde, alimentação, moradia, recreativas, culturais, sexuais e sua relação com a família e a comunidade, o que sem dúvidas deve ser levado em conta.

Não obstante, salienta-se que fatores positivos se relacionam com o aluno oriundo da EJA, sendo estes "determinantes" não somente no ingresso na faculdade, mas, de igual forma, durante o período em que lá se encontrarem, em face das características comuns que cercam os cercam, quais se traduzem pela valorização e motivação deste público em específico, fazendo-os vislumbrar novos horizontes na formação em nível superior.

Certo que, uma vez na universidade, àqueles que alcançaram tal status já não deixarão a oportunidade escapar de suas mãos. Isso se dá pelo fato dos egressos da EJA enxergarem no curso superior uma vitória, a consecução dos sonhos projetados para o futuro, o reconhecimento das habilidades e de posicionamento diante de temáticas pontuais, além da autenticidade das convicções, fatores que cooperam para a administração do tempo, no contexto da universidade e vida pessoal etc.

Haddad (1997) chama a atenção, referindo-se às peculiaridades da EJA, para o fato de ser uma modalidade de educação que "prepara o indivíduo para servir a fins RC: 89981

Disponível em: https://www.nucleodoconhecimento.com.br/educacao/ensino-no$\underline{\text { estado }}$ 
determinados". Pari passu - no mesmo sentido, Moura (2003) sedimenta o entendimento de que, à título de isonomia nas oportunidades, quando o enfoque real da modalidade envolve a superação do estigma de "educação compensatória", certamente proporciona uma educação que transforma pessoas em sujeitos participativos e preparados para lançarem-se nos sonhos e objetivos, sobretudo, à progressão na escolaridade.

Assim, verifica-se que os universitários oriundos da EJA, muitas vezes estigmatizados pelo preconceito, contornam adversidades e as vencem na esperança configurada nos esforços diários, na expectativa de um novo capítulo a trilhar em cada cenário, apropriadamente escrevem como será o futuro, em face do acesso ao conhecimento e do exercício da cidadania.

\subsubsection{PERCEPÇÃO DE EX-ALUNOS DA EJA SOBRE ACESSO AO ENSINO SUPERIOR: DOS MOTIVOS QUE CERCAM O ALUNO A PROSSEGUIR OU NÃO NOS ESTUDOS}

No intuito de sedimentar o entendimento sobre a Educação de Jovens e Adultos e suas características servirem de fator preponderantemente positivo para o ingresso, permanência e conclusão de uma faculdade, formulou-se uma base de dados estatísticos com vistas a analisar as expectativas dos alunos em face da possibilidade de acesso aos cursos superiores, mais especificamente os que concluíram o Ensino Médio via Educação de Jovens e Adultos (EJA).

As estatísticas contribuem ainda para elucidar até que ponto essa modalidade projeta ou não o acesso ao ensino superior, se comparado ao ensino regular. Com recorte espacial para o Estado de Roraima, direcionou-se o foco para questões que envolvem o "acesso" à Universidade Pública. Na busca de respostas às hipóteses, considerouse os aspectos que norteiam a EJA e suas características específicas, especialmente a essencialidade do público-alvo, além do contexto educacional brasileiro, analisado genericamente.

RC: 89981

Disponível em: https://www.nucleodoconhecimento.com.br/educacao/ensino-no$\underline{\text { estado }}$ 
As entrevistas deram-se com 30 (trinta) voluntários, momento em que se colecionou dados de ingresso de egressos da EJA em cursos superiores e, ainda, as expectativas daqueles que não vivenciaram o mundo acadêmico. Quanto ao público-alvo, compôsse de alunos e ex-alunos da EJA, entre 18 e 40 anos, trabalhadores e que pretendem prestar vestibular. Com base no questionário da Entrevista constante do "Apêndice A", tendo sido compilados os dados, foram obtidos os seguintes resultados:

1. Dos motivos que motivaram a escolha da Educação de Jovens e Adultos como opção para conclusão do Ensino Médio, 76,7\% dos entrevistados responderam ser a "necessidade de trabalhar no horário diurno", ou seja, comercial. As questões relacionadas às responsabilidades para com a "família, esposo(a)/filhos" vem na sequência, com $23,3 \%$ e pelo motivo de "tempo de conclusão do ensino médio ser menor ( 1,5 ano)" em relação ao ensino regular, listou-se em terceira posição, conforme mostra o Gráfico 1.

Gráfico 1 - Quanto aos motivos que motivaram a escolha da EJA para conclusão do Ensino Médio.

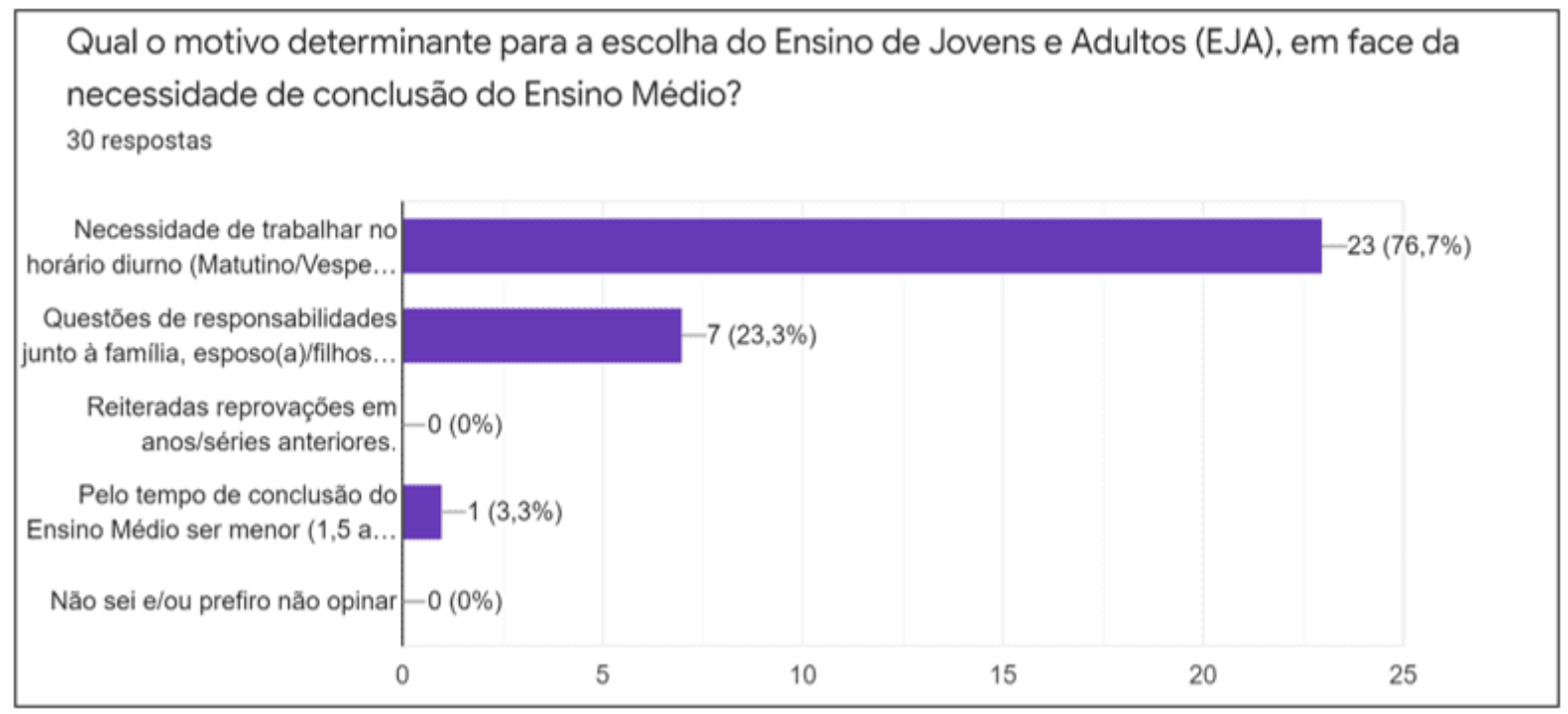

Fonte: Dados da Pesquisa - Formulário Google Forms - Apêndice A - Entrevista

RC: 89981

Disponível em: https://www.nucleodoconhecimento.com.br/educacao/ensino-noestado 
2. Sobre a importância do Ensino Superior para o futuro profissional dos entrevistados, $76,7 \%$ consideram "extremamente importante". $20 \%$ relataram ser "muito importante" e 3,3\% consideram "importante", de acordo com o Gráfico 2.

Gráfico 2 - Sobre a importância do Ensino Superior para o futuro profissional do entrevistado.

Que importância o Ensino Superior tem para seu futuro profissional?

30 respostas

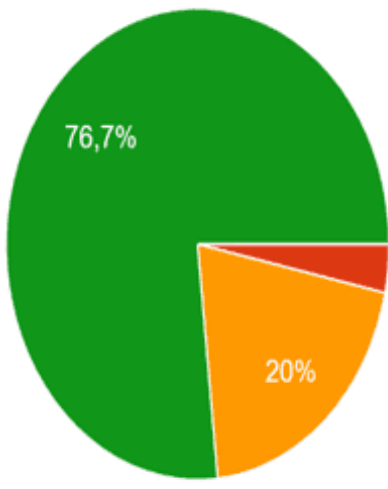

Pouco importante.

Importante

Muito importante

Extremamente importante

Não sei e/ou prefiro não opinar

Fonte: Dados da Pesquisa - Formulário Google Forms - Apêndice A - Entrevista

3. Quanto a crença de ser possível ao ex-aluno da EJA ser aprovado no vestibular e cursar uma faculdade, 56,7\% dizem "ser possível a aprovação", com 40\% afirmando que "só depende do ex-aluno da EJA" e 3,3\% "pensa que seja difícil de ser aprovado", vide Gráfico 3.

RC: 89981

Disponível em: https://www.nucleodoconhecimento.com.br/educacao/ensino-no$\underline{\text { estado }}$ 
Gráfico 3 - Quanto a crença da possibilidade do egresso da EJA ser aprovado no vestibular e cursar a faculdade.

Você acredita ser possivel um(a) ex-aluno(a) do EJA ser aprovado em processo seletivo de Vestibular e cursar uma Faculdade?

30 respostas

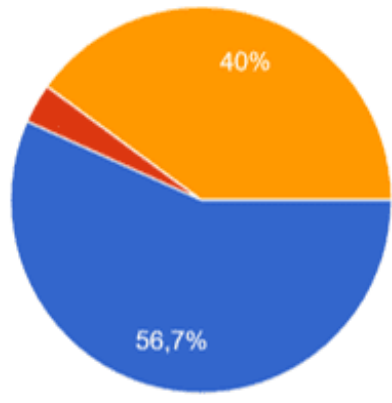

Acho ser possivel a aprovaçăo

Penso que seja dificil ser aprovado

Depende somente do ex-aluno do EJA

Não vê qualquer possibilidade

Não sei dizer e/ou prefiro năo opinar

Fonte: Dados da Pesquisa - Formulário Google Forms - Apêndice A - Entrevista

4. Dos índices de aprovação em processo seletivo para ingresso em cursos superiores, por ex-alunos da EJA, vislumbra-se entre os entrevistados que $83,3 \%$ "já foram aprovados" e 16,7\% afirmaram que "nunca tentaram" a citada aprovação, verificado no Gráfico 4.

RC: 89981

Disponível em: https://www.nucleodoconhecimento.com.br/educacao/ensino-no$\underline{\text { estado }}$ 
Gráfico 4 - Dos índices de aprovação no vestibular para ingresso em cursos superiores por ex-alunos/EJA.

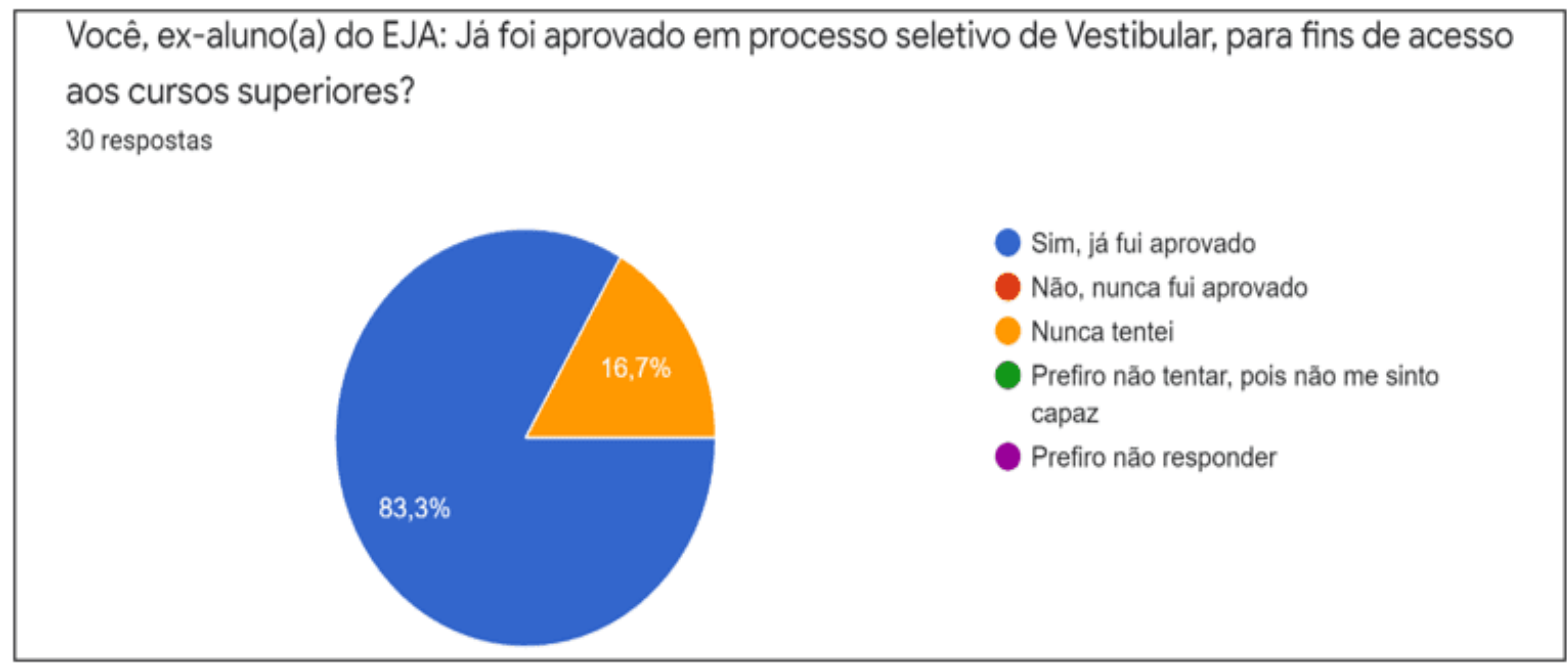

Fonte: Dados da Pesquisa - Formulário Google Forms - Apêndice A - Entrevista

5. Já em relação aos que tiveram acesso aos cursos superiores, dos entrevistados, 43,3\% asseveram que "já concluíram um curso superior", 23,3\% disseram "não ter concluído" a faculdade, $20 \%$ afirmaram "estar cursando normalmente o ensino superior, com previsão de término no período correto" e 13,3\% revelaram "já ter cursado alguns semestres, mas desanimaram e abandonaram os estudos", conforme demonstrado no Gráfico 5.

RC: 89981

Disponível em: https://www.nucleodoconhecimento.com.br/educacao/ensino-noestado 
Gráfico 5 - Em relação aos que tiveram acesso aos cursos superiores.

Você, ex-aluno(a) do EJA: Já concluiu uma faculdade?

30 respostas

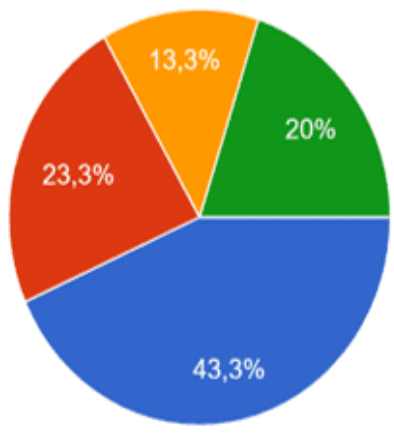

Sim, já conclui um curso superior

Não, não consegui concluir um curso superior

Já cursei alguns semestres, mas desanimei e abandonei os estudos

Estou cursando normalmente o ensino superior, com previsão de conclusão no período correto

Prefiro não opinar

Fonte: Dados da Pesquisa - Formulário Google Forms - Apêndice A - Entrevista

6. Consoante ao término da graduação, questionou-se a pretensão dos entrevistados em prosseguir nos estudos e cursar um curso de pós-graduação, à título de especialização, dos quais $80 \%$ disseram que "pretende continuar os estudos" e $20 \%$ afirmaram "nunca ter cursado uma faculdade", de acordo com o Gráfico 6.

RC: 89981

Disponível em: https://www.nucleodoconhecimento.com.br/educacao/ensino-no$\underline{\text { estado }}$ 
Gráfico 6 - Quanto ao término da graduação e pretensões de cursar pós-graduação.

Pretende fazer algum curso de pós-graduação ou está satisfeito com o ensino superior? 30 respostas

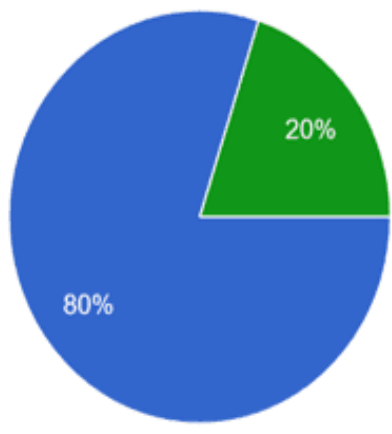

Pretendo continuar meus estudos

Não pretendo continuar

Se terminar a faculdade, já estarei satisfeito

Nunca cursei uma faculdade

Não me sinto capaz de continuar

Fonte: Dados da Pesquisa - Formulário Google Forms - Apêndice A - Entrevista

7. Por fim, sobre ter cursado algum curso de pós-graduação, em nível de especialização, mestrado ou doutorado, $76,7 \%$ afirmaram "nunca ter cursado uma pós-graduação, mas pretende começar em breve", $20 \%$ disseram ser possuidores de curso de pós-graduação em nível de "especialização" e 3,3\% revelaram ser possuidor de curso de Mestrado, consoante o verificado no Gráfico 7.

RC: 89981

Disponível em: https://www.nucleodoconhecimento.com.br/educacao/ensino-no$\underline{\text { estado }}$ 
Gráfico 7 - Quanto já ter cursado pós-graduação.

Já fez algum curso de pós-graduação, qual?

30 respostas

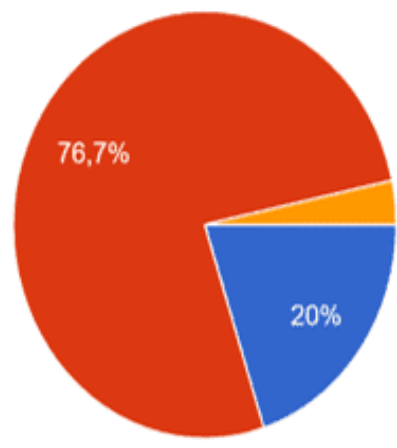

Sim, Especialização Latu Sensu

Nunca cursei pós-graduaçăo, mas pretendo começar em breve

Sim, Mestrado

Sim, Doutorado

Sou aluno de Mestrado ou Doutorado

Fonte: Dados da Pesquisa - Formulário Google Forms - Apêndice A - Entrevista

A presente entrevista é reveladora, sobretudo considerando o exposto na presente pesquisa, no que concerne ao contexto da Educação de Jovens e Adultos, o perfil do alunado desta modalidade, em face dos fatores que cercam o dia a dia do trabalhador estudante.

Ficaram demonstrados nos resultados que existem os fatores presentes nas decisões, traduzidos pela força motriz que os une, claramente evidenciado nas respostas de quase a totalidade das perguntas feitas aos entrevistados, qual seja, a "motivação".

É impressionante exaurir esse extrato de realidade que move a pessoa com ânimo para vencer, superar suas limitações e deixar seu legado à posteridade, a exemplo do pesquisador.

\subsubsection{SUPERAÇÃO: EX-ALUNO DA EJA OBTÉM 1ํ LUGAR NO PROCESSO SELETIVO DISCENTE PARA PROGRAMA DE PÓS- GRADUAÇÃO STRICTO SENSU EM DIREITO}

RC: 89981

Disponível em: https://www.nucleodoconhecimento.com.br/educacao/ensino-noestado 
No viés da democratização da educação, a presente pesquisa projeta luz ao sermão de que todo esforço tem sua recompensa e que, não obstante às dificuldades e percalços no caminho, o ser humano é dotado da capacidade de se reerguer, de tirar forças da fraqueza e continuar lutando pelos sonhos, perseverando na corrida pela satisfação, o que tecnicamente conhecemos por resiliência. Nesse sentido, a exemplo de motivação, relata-se em termos panorâmicos a trajetória acadêmica do pesquisador que, por questões óbvias e imparcialidade, não compôs a relação dos entrevistados.

De origem singela, cursou integralmente em escola pública o primário (1 $1^{a}$ a $4^{\underline{a}}$ séries) e o ginásio ( $5^{\underline{a}}$ a $8^{\underline{a}}$ séries), duas nomenclaturas utilizadas, à época, no $1^{0}$ grau, hoje ensino fundamental. Desta etapa, registra-se uma reprovação na $7^{\underline{a}}$ série, na disciplina de matemática. No trocadilho de palavras, não se registra qualquer indisciplina ou maiores problemas que pudessem se relacionar com tal falha na sequência lógica de progressão das séries do ensino fundamental.

Contudo, finalizar o ensino médio não foi tarefa tão simples. A experiência na $2^{\underline{a}}$ série do então $2^{\circ}$ grau foi por demais desastrosa. Em face de (entre outros) greve de professores combinada com necessidade de trabalhar para contribuir na renda familiar, deu-se início a uma série de "desistências" no $2^{\circ}$ ano $/ 2^{\circ}$ grau. Destarte, o problema não era de "reprovação", mas estava relacionado à "evasão escolar em razão de trabalho". Assim, após inúmeras rematrículas e novas tentativas de conclusão dos estudos básicos, a frustação foi recorrente.

Das possibilidades existentes, à época, para que se finalizasse o ensino médio, houve tentativas diversas, entre as quais se listam: a) "Provão do $2^{\circ}$ grau", hoje no formato do Exame Nacional para Certificação de Competências de Jovens e Adultos (Encceja), não obtendo sucesso, em face de sempre restar uma disciplina a ser vencida ao final; b) A Educação de Jovens e Adultos, no formato de disciplinas sequenciais, a cada três meses, até que se completasse um ano e seis meses, o que também registrou-se evasão escolar; c) Em última tentativa, matriculou-se no formato 
atual da EJA, conquistando aprovação na $2^{\mathrm{a}}$ e a $3^{\mathrm{a}}$ série do ensino médio, tendo concluído em doze meses.

Não demorou para que, satisfeitas as exigências do ensino médio completo, pudesse ser aprovado em concurso público para preenchimento de vagas no Curso de Formação de Soldados da Polícia Militar do Estado de Roraima - CFSd PM 2000, o que após concluso o referido curso em 1ํ lugar, foi empossado na Graduação de Soldado do Quadro de Praças Músicos Policiais Militares, permanecendo na Unidade Militar até os dias presentes, após sucessivas promoções ao longo da carreira, alcançando o Posto de Capitão no exercício da função de Subcomandante da Banda de Música da Polícia Militar de Roraima.

Acrescenta ainda na carreira militar, a conclusão em 11.12.2020 do Curso de Aperfeiçoamento de Oficiais - CAO, do Quadro de Oficiais Músicos Policiais Militares, em que obteve classificação final em 1 lugar, com coeficiente de rendimento - QR de 9,954 . Não obstante às conquistas, compartilha o conhecimento acumulado nas instruções das ministradas na Academia de Polícia Integrada Coronel Santiago APICS, como Instrutor das Disciplinas de Criminalística, Criminologia Aplicada à Segurança Pública, Direito Penal e Processual Penal, Direitos Humanos e Cidadania, Direito Penal Militar e Processual Penal Militar.

Em fevereiro de 2004 deu início à formação superior, permanecendo em curso até dezembro de 2008, momento em concluiu sua primeira faculdade - Bacharelado em Teologia, na Faculdade de Ciências, Educação e Teologia do Norte do Brasil FACETEN, área da ciência que dedicou vários anos em pesquisa, como Professor de Teologia, Língua Grega, além de Cultura e Língua Hebraica, nos cursos de Graduação em Teologia, no Instituto de Teologia e Filosofia de Roraima - ITEFIR, em parceria com a FACETEN.

Prosseguindo na jornada acadêmica, em face das necessidades relacionadas à função pública que exerce, decidiu cursar o Curso Superior de Tecnologia em Gestão Pública, pari passu - simultaneamente ao Curso Superior de Tecnologia em RC: 89981

Disponível em: https://www.nucleodoconhecimento.com.br/educacao/ensino-noestado 
Investigação Forense e Perícia Criminal, concluindo as duas graduações na mesma data, em 11.02.2018, pelo Centro Universitário Estácio de Ribeirão Preto/SP.

Como meta pessoal estabelecida, formou-se no Curso de Bacharelado em Direito, no Centro Universitário Estácio da Amazônia, colando grau em 22.07.2020. À título de Graduações, ainda coleciona o Curso de Licenciatura em História, com colação de grau em 11.09 e, ainda, a conclusão de dois Cursos de Licenciatura ao término do semestre 2021.1: Licenciatura em Ciências Humanas e a Licenciatura em Letras Língua Portuguesa, todas pelo Centro Universitário Estácio de Ribeirão Preto/SP.

Concluiu ainda três cursos de Pós-Graduação Lato Sensu, sendo: Especialização em Direito Militar, pela Faculdade Verbo Educacional (Verbo Jurídico); Especialização em Direito Penal e Processual Penal, pela Universidade Estácio de Sá - UNESA; e a Especialização em Direito Público: Constitucional, Administrativo e Tributário, no Centro Universitário Estácio da Amazônia.

Em face da publicação do Edital no. 109/2020, de 15 de outubro de 2020, que tornou público o Processo Seletivo Discente para ingresso no Programa de Pós-Graduação Stricto Sensu em Direito, Cursos de Mestrado e Doutorado, da Universidade Católica de Santos - UniSantos, concorreu no certame apresentando o Pré-Projeto de Pesquisa intitulado: "Fechamento de Fronteiras e Direito Internacional: Questões à luz do caso dos venezuelanos em Roraima", qual obteve classificação final em "10 lugar" (ampla concorrência), garantindo a matrícula na primeira, das 22 (vinte e duas) vagas, do Curso de Mestrado em Direito, Área de Concentração: Direito Internacional 2021 2022.

De suas publicações científicas, destaca-se o Artigo Científico intitulado: "A Crise Migratória Venezuelana e o Fechamento da Fronteira Brasil/Venezuela: Uma Análise à Luz do Direito Humanitário", tema do seu TCC em Direito, posteriormente publicado nos Anais do XI Encontro de Iniciação Científica da Estácio da Amazônia (2019), depois na Revista Científica Brazilian Journal of Development (2020) e em seu formato

RC: 89981

Disponível em: https://www.nucleodoconhecimento.com.br/educacao/ensino-no$\underline{\text { estado }}$ 
final publicado como Capítulo do Livro Tópicos em Ciências Sociais - Volume 3 (2020).

Ainda no viés de publicações científicas, apresentou seu TCC na Pós-Graduação em Direito Penal e Processo Penal, intitulado: "Rebeliões e Crimes Bárbaros na Penitenciária Agrícola do Monte Cristo (PAMC): A Crise no Sistema Prisional de Roraima", obtendo nota máxima, o qual foi submetido e aprovado a compor os Anais do XII Encontro de Iniciação Científica e Extensão da Estácio da Amazônica (2020), posteriormente publicado na Revista Científica Revista Multidisciplinar Pey Këyo Científico (2020) e, por fim, firmou-se como Capítulo do Livro "Direito: Justiça, Políticas Públicas e as Relações entre Estado e Sociedade" (2021).

De Pesquisador à Avaliador Externo, em Pareceres Acadêmicos de Artigos, esse foi o passo mais recente, em face do convite recebido da Editora de la Revista de la Facultad de Derecho da Universidad de da República - Montevideo, Uruguay, momento em contribuiu com o Parecer Avaliativo do Artigo intitulado: "Como transformar a escola do crime em um sistema prisional ressocializador", submetido à aprovação na citada revista científica (2021).

Compõe ainda a Comissão Organizadora responsável pelo processo de publicação do livro em formato eletrônico (e-book), o qual reunirá os Trabalhos de Conclusão de Curso dos alunos formados nos Cursos de Formação Inicial e Continuada (FIC) de Aperfeiçoamento de Oficiais (CAO) e Superior de Polícia (CSP) da Polícia Militar de Roraima em parceria com o Instituto Federal de Roraima - IFRR/CBV.

Por fim, da paixão pela Língua Hebraica, qual leciona desde 2009, nasceu o projeto do livro: "Manual de Alfabetização da Língua Hebraica", já em fase final de compilação, resultado de 12 (doze) anos de dedicação em pesquisa, com breve previsão de publicação.

O que dizer de tudo isso? Sem dúvidas, toda essa trajetória de sucesso é perfeitamente traduzida na palavra "resiliência".

RC: 89981

Disponível em: https://www.nucleodoconhecimento.com.br/educacao/ensino-no$\underline{\text { estado }}$ 
Não obstante ser de origem simples, com a infância regrada economicamente falando, ter convido com os traumas do divórcio dos pais, em razão disso ter iniciado nos trabalhos braçais desde os 9 (nove) anos de idade, contribuindo no sustento da casa, começado aos 13 (treze) anos a vida morando sozinho, percorrendo uma série de trabalhos para a manutenção própria e dos estudos etc, "não desanimar" foi o segredo, (vontade não lhe faltou), mas como já citado, existe no interior das pessoas uma força motriz que os impulsionam a querer vencer, essa "motivação" sem dúvidas foi fator determinante para que na atualidade os frutos de uma semeadura lenta e progressiva pudesse ser colhidos e, assim, superar suas limitações e deixar seu legado à posteridade. Essa é a máxima a praticar.

\section{CONCLUSÃO}

Após constatação, verificou-se que a Educação de Jovens e Adultos (EJA) segue a proposta constitucional, ao se confirmar como ferramenta garantidora do acesso à educação básica aos que não usufruíram na idade própria, além de ser uma modalidade de ensino que se adequa às condições do educando, assertiva que se traduz pela efetivação do direito subjetivo à educação, a todos estendido.

Aferiu-se os motivos determinantes na permanência ou abandono escolar por parte do alunado, destacando-se o contexto econômico do público-alvo dessa modalidade, em que é marcado pela ausência da isonomia, uma vez considerados os índices de permanência na escola e conclusão dos estudos em nível de educação básica no prazo correto e, também, as circunstâncias agravantes que determinam a decisão de estudar ou trabalhar para garantir a subsistência.

Analisada sob o crivo da democratização, restou provado os aspectos jurídicoseducacionais que reconhecem ser a EJA um exercício da cidadania, consubstanciados nas legislações aplicáveis, as características específicas do público-alvo e os materiais didáticos destinados à modalidade de ensino em tela.

RC: 89981

Disponível em: https://www.nucleodoconhecimento.com.br/educacao/ensino-noestado 
Contudo, reconhece-se existir muito a ser feito no sedimentar cada vez mais as especificidades que contextualizam a Educação de Jovens e Adultos, à exemplo do material didático aprimorado direcionado ao público-alvo, fato que se verifica ainda ser uma disparidade presente entre a faixa etária do alunado e os recursos e práticas pedagógicas, disponíveis para o momento.

Não obstante às dificuldades, quantificou-se nos recortes estatísticos que o fato de concluir o ensino médio na modalidade EJA não impede ou diminui as possibilidades de o egresso cursar uma faculdade, ao contrário, somam-se às intempéries, o fator resiliência, encontrado quase em sua totalidade nos entrevistados, o que os induzem a prosseguir.

Por fim, a trajetória acadêmica e profissional do pesquisador corrobora e dá luz ao sermão ao firmar convencimento de que todo esforço tem sua recompensa e que, não obstante às dificuldades e percalços no caminho, o ser humano é dotado da capacidade de se reerguer, de tirar forças da fraqueza e continuar lutando pelos sonhos, perseverando na corrida pela satisfação, o que tecnicamente conhecemos por resiliência, esperança e positividade.

\section{REFERÊNCIAS}

ANDRADE, G. P. de; SOLEK, R. C. A Crise Migratória Venezuelana e o Fechamento da Fronteira Brasil/Venezuela: Uma Análise à Luz do Direito Humanitário. In.: Tópicos em Ciências Sociais - Volume 3, 2020, doi:10.36229/978-65-86127-34-8.cap.06. Disponível em: <https://poisson.com.br/2018/produto/topicos-em-ciencias-sociaisvolume-3/> Acesso em: 11 Abr. 2021.

ANDRADE, G. P. de. Rebeliões e Crimes Bárbaros na Penitenciária Agrícola do Monte Cristo (PAMC): A Crise no Sistema Prisional de Roraima. In.: Direito: Justiça, Políticas Públicas e as Relações entre Estado e Sociedade, 2021, pp. 78-95., doi:10.22533/at.ed.1922108017.

Disponível

em: 
<https://www.finersistemas.com/atenaeditora/index.php/admin/api/artigoPDF/46247> Acesso em: 11 Abr. 2021.

. G. P. de. Rebeliões e Crimes Bárbaros na Penitenciária Agrícola do Monte Cristo (PAMC): A Crise no Sistema Prisional de Roraima. In.: Revista Multidisciplinar Pey Këyo Científico - ISSN 2525-8508, Vol. 6, № 4 (2020). Disponível em: $<$ http://periodicos.estacio.br/index.php/pkcroraima/article/viewArticle/9166> Acesso: 05 Mai 2021.

ARANHA, M. L. de A. História da educação. São Paulo: Moderna, 2001.

BANDEIRA, D. Materiais Didáticos. Curitiba: IESDE, 2009. Disponível em: <file://C:/Users/USUARIO/Downloads/Materiais_didaticos.pdf> Acesso: 02 Mai 2021.

BELEZA, J. O.; NOGUEIRA, E. M. L. Contexto histórico da Educação de Jovens e Adultos no Brasil. Universidade Federal do Amazonas - UFAM. RECH - Revista Ensino de Ciências e Humanidades - Cidadania, Diversidade e Bem-estar. ISSN 2594-8806. Ano 4, Vol. IV, N. 2, 2020: Temas livres em Ensino de Ciências e

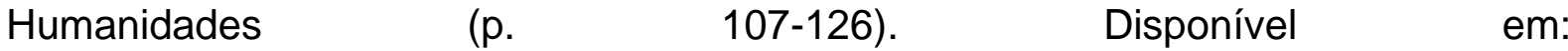
$<$ https://www.periodicos.ufam.edu.br/index.php/rech/article/view/7958> Acesso: 10 Abr. 2021.

BRASIL. CÂMARA DOS DEPUTADOS. LEI № 5.692, DE 11 DE AGOSTO DE 1971. (Legislação Informatizada - Lei de Diretrizes e Base de 1971 - Publicação Original). Disponível em: <https://www2.camara.leg.br/legin/fed/lei/1970-1979/lei-5692-11agosto-1971-357752-publicacaooriginal-1-pl.html> Acesso: 15 Abr. 2021.

BRASIL. Constituição da República Federativa do Brasil de 1988. Brasília, DF: Senado Federal, $1988 . \quad$ Disponível em: <http://www.planalto.gov.br/ccivil_03/constituicao/constituicao.htm> Acesso: 13 Abr. 2021.

RC: 89981

Disponível em: https://www.nucleodoconhecimento.com.br/educacao/ensino-no$\underline{\text { estado }}$ 
. MINISTÉRIO DA EDUCAÇÃO - CONSELHO NACIONAL DE EDUCAÇÃO. Parecer CNE/CEB 11/2000 - Processo n.- 23001.000040/2000-55 - Aprovado em 10 de maio de 2000. (Estabelece Diretrizes Curriculares Nacionais para a Educação de Jovens e Adultos). Disponível em: <http://portal.mec.gov.br/cne/arquivos/pdf/pceb011_00.pdf> Acesso em: 15 Abr. 2021.

- MINISTÉRIO DA EDUCAÇÃO (MEC). Programa Brasil Alfabetizado. Disponível em: <http://portal.mec.gov.br/programa-brasil-alfabetizado> Acesso: 16 Abr. 2021.

- MINISTÉRIO DA EDUAÇÃO (MEC). Lei de Diretrizes e Bases da Educação Nacional n 9.394/96. Disponível em: <http://www.mec.gov.br> Acesso: 10 Abr. 2021.

. PRESIDÊNCIA DA REPÚBLICA. DECRETO N. 591, DE 6 DE JULHO DE 1992 - Pacto Internacional dos Direitos Econômicos, Sociais e Culturais. (Adotada pela Resolução n.2.200-A (XXI) da Assembleia Geral das Nações Unidas, em 16 de dezembro de 1966 e ratificada pelo Brasil em 24 de janeiro de 1992). Disponível em: <http://www.planalto.gov.br/ccivil_03/decreto/1990-1994/d0591.htm> Acesso: 20 Abr. 2021.

COMISSÃO INTERAMERICANA DE DIREITOS HUMANOS. Declaração Americana dos Direitos e Deveres do Homem. (Aprovada na Nona Conferência Internacional Americana, Bogotá, 1948). Disponível em: $<$ https://www.cidh.oas.org/basicos/portugues/b.declaracao_americana.htm> Acesso: 20 Abr. 2021.

. TRIBUNAL SUPERIOR ELEITORAL. Decreto no 3.029, de 9 de janeiro de 1881 - Lei Saraiva (Reforma a legislação eleitoral). Disponível em: <https://www.tse.jus.br/eleitor/glossario/termos/lei-saraiva> Acesso: 23 Abr. 2021.

RC: 89981

Disponível em: https://www.nucleodoconhecimento.com.br/educacao/ensino-noestado 
CARDOSO, M. A.; PASSOS, G. de A. L. dos. Reflexões sobre a educação de jovens e adultos e a formação docente. (2016). Disponível em: $<$ https://educacaopublica.cecierj.edu.br/artigos/16/25/reflexes-sobre-a-educao-dejovens-e-adultos-e-a-formao-docente> Acesso: 14 Abr. 2021.

CENTRO UNIVERSITÁRIO ESTÁCIO DA AMAZÔNIA. Anais do EICEA 2019 - XI Encontro de Iniciação Científica da Estácio Amazônia. Publicado em 20/12/2019 ISBN: 978-85-5722-366-0 - DOI: 10.29327/111655. Disponível em: <https://www.even3.com.br/anais/xieicea/> Acesso: 05 Mai 2021.

\section{Anais do EICEA 2019 - XII Encontro de Iniciação Científica e Extensão} da Estácio Amazônia. Publicado em 03/12/2020 - ISBN: 978-85-5722-366-0. Disponível em: <https://www.even3.com.br/anais/xiieicea/> Acesso: 05 Mai 2021.

CORTADA, S. EJA - Educação de Jovens e Adultos e seus diferentes contextos - Coleção Pedagogia de A a Z - Vol. 12. Jundiaí: Paco Editorial, 2014.

FORMULÁRIOS, Google. A EDUCAÇÃO DE JOVENS E ADULTOS (EJA): Uma ferramenta de democratização do ensino. Ferramenta Google de aplicação de formulários de pesquisa. [Versão Digital]. Disponível em: <https://docs.google.com/forms/d/1Y3aMt8AVQnVxqNFb_ZFIUdEQ0z7TkGL2Th4oZ ggc_Fs/edit> Acesso: 21 Abr. 2021.

FREIRE, P. A importância do ato de ler: em três artigos que se completam. São Paulo: Cortez, 1999.

P. Conscientização: Teoria e prática da libertação: uma introdução ao pensamento de Paulo Freire. (Trad. de Kátia de Mello e Silva). São Paulo: Cortez \& Moraes, 1979. [Versão Digital]. Disponível em: $<$ https://www.fpce.up.pt/ciie/sites/default/files/Paulo\%20Freire\%20\%20Conscientiza\%C3\%A7\%C3\%A3o_pp.5-19.pdf> Acesso: 15 Abr. 2021. 
HADDAD, S. A educação de pessoas jovens e adultas e a nova LDM. São Paulo, 1997.

$<$ http://www.bibliotecadigital.abong.org.br/bitstream/handle/11465/1767/3.pdf?seque nce=1> Acesso: 21 Abr. 2021.

INSTITUTO NACIONAL DE ESTUDOS E PESQUISAS - INEP. Matrículas na educação de jovens e adultos caem; 3,3 milhões de estudantes na EJA em 2019. Disponível em:

$<$ http://inep.gov.br/artigo//asset_publisher/B4AQV9zFY7Bv/content/matriculas-na-educacao-de-jovens-eadultos-cai-3-3-milhoes-de-estudantes-na-eja-em-2019/21206> Acesso: 17 Abr. 2021.

LEHENBAUER, S.; SCHEIBEL, M. F. (orgs). Saberes e singularidades na educação de jovens e adultos. Porto Alegre: Mediação, 2010.

MACHADO, N. J. Educação: projetos e valores. 3 ed. São Paulo: Escrituras Editoras, 2002.

MÉSZÁROS, I. A educação para além do capital. São Paulo: Boitempo, 2008. [Versão Digital]. Disponível em: <http://www.gepec.ufscar.br/publicacoes/livros-ecolecoes/livros-diversos/a-educacao-para-alem-do-capital-istvan-meszaros.pdf> Acesso: 10 Abr. 2021.

MOTA, R. da S. Aprendizagem do adulto e correspondentes metodologias. Campinas, SP: [s.n.], 2009. Trabalho de Conclusão de Curso (Especialização em Educação de Jovens e Adultos) - Universidade Estadual de Campinas, Faculdade de Educação. Disponível em: <http://www.bibliotecadigital.unicamp.br/document/?code=41039> Acesso: $15 \mathrm{Abr}$. 2021.

MOURA, M. da G. C.. Educação de Jovens e Adultos: um olhar sobre sua trajetória histórica. Curitiba: Educarte, 2003. 
NERI, A. L. Velhice e sociedade. 2. Ed. Campinas, SP: Papirus, 2008.

PAIVA, V. P. História da educação popular no Brasil. 6 ed. São Paulo: Edições Loyola, 2003.

, V. P. Educação popular e educação de jovens e adultos. Rio de Janeiro: Edições Loyola, 2006.

SANTOS, J. N.; SILVA, J. H. da. Educação profissional e a EJA: uma análise da oferta do Proeja nos institutos federais da Bahia. Revista multidisciplinar de Ensino, Pesquisa e Extensão e Cultura. V. 9 - N.22 - 2020.

SILVA, N. da. Processo de afiliação de egressos da EJA no ensino superior: desafios e propostas à docência universitária, 2015. Disponível em: $<$ https://www.revistas.uneb.br/index.php/educajovenseadultos/article/view/1389> Acesso: 20 Abr. 2021.

UNIVERSIDAD DE LA REPÚBLICA - URUGUAY. Revista de la Facultad de Derecho - ISSN 0797-8316 / eISSN 2301-0665, (2021). Disponível em: <https://revista.fder.edu.uy/index.php/rfd> Acesso: 05 Mai 2021.

UNIVERSIDADE CATÓLICA DE SANTOS (UNISANTOS). EDITAL №. 109/2020. Processo Seletivo Discente do Programa de Pós-Graduação Stricto Sensu em Direito, cursos de Mestrado e Doutorado. Disponível em: $<$ https://www.unisantos.br/wp-

content/uploads/2020/10/UNISANTOS_2020_EDI_109_ProcessoSeletivoStrictoSens u_Direito.pdf> Acesso: 04 Mai 2021.

. EDITAL №. 144/2020. Processo Seletivo Discente para o Programa de Pós-Graduação Stricto Sensu em Direito - Resultado Mestrado. (Seletivo regido pelo Edital o․ 109/2020, de 15 de outubro de 2020). Disponível em: <https://www.unisantos.br/graduacao/wp-content/uploads/sites/4/2020/12/EDITAL- 
$\mathrm{N} \% \mathrm{C} 2 \% \mathrm{BA}-$

144_2020_UNISANTOS_P\%C3\%B3s_DIREITO_Resultado_final_Ed.109.pdf> Acesso: 04 Mai 2021.

VIEIRA, M. C. Fundamentos históricos, políticos e sociais da Educação de Jovens e Adultos: aspectos históricos da educação de jovens e adultos no Brasil. Brasília, DF: UnB, CEAD, 2004.

\section{APÊNDICE A - ENTREVISTA}

A educação de jovens e adultos (EJA): Uma ferramenta de democratização do ensino. Formulário de Pesquisa sobre a Educação de Jovens e Adultos (EJA) como ferramenta de democratização do ensino, considerando as especificidades desta modalidade, seu público-alvo e contexto educacional brasileiro. Visa, ainda, contribuir para elucidar até que ponto essa modalidade contribui ou não para o acesso ao ensino superior, por ex-alunos da EJA, se comparado ao ensino regular.

Qual o motivo determinante para a escolha do Ensino de Jovens e Adultos (EJA), em face da necessidade de conclusão do Ensino Médio?

- Necessidade de trabalhar no horário diurno (Matutino/Vespertino).

- Questões de responsabilidades junto à família, esposo(a)/filhos(as).

- Reiteradas reprovações em anos/séries anteriores.

- Pelo tempo de conclusão do Ensino Médio ser menor (1,5 ano)

- Não sei e/ou prefiro não opinar

Que importância o Ensino Superior tem para seu futuro profissional?

- Pouco importante.

- Importante

- Muito importante

- Extremamente importante

RC: 89981

Disponível em: https://www.nucleodoconhecimento.com.br/educacao/ensino-noestado 
- Não sei e/ou prefiro não opinar

Você acredita ser possível um(a) ex-aluno(a) do EJA ser aprovado em processo seletivo de Vestibular e cursar uma Faculdade?

- Acho ser possível a aprovação

- Penso que seja difícil ser aprovado

- Depende somente do ex-aluno do EJA

- Não vê qualquer possibilidade

- Não sei dizer e/ou prefiro não opinar

Você, ex-aluno(a) do EJA: Já foi aprovado em processo seletivo de Vestibular, para fins de acesso aos cursos superiores?

- Sim, já fui aprovado

- Não, nunca fui aprovado

- Nunca tentei

- Prefiro não tentar, pois não me sinto capaz

- Prefiro não responder

Você, ex-aluno(a) do EJA: Já concluiu uma faculdade?

- Sim, já conclui um curso superior

- Não, não consegui concluir um curso superior

- Já cursei alguns semestres, mas desanimei e abandonei os estudos

- Estou cursando normalmente o ensino superior, com previsão de conclusão no período correto

- Prefiro não opinar

Pretende fazer algum curso de pós-graduação ou está satisfeito com o ensino superior?

- Pretendo continuar meus estudos

RC: 89981

Disponível em: https://www.nucleodoconhecimento.com.br/educacao/ensino-noestado 
- Não pretendo continuar

- Se terminar a faculdade, já estarei satisfeito

- Nunca cursei uma faculdade

- Não me sinto capaz de continuar

Já fez algum curso de pós-graduação, qual?

- Sim, Especialização Latu Sensu

- Nunca cursei pós-graduação, mas pretendo começar em breve

- Sim, Mestrado

- Sim, doutorado

- Sou aluno de Mestrado ou Doutorado

(Formulário com cópia das respostas será enviada para os endereços de e-mail fornecidos).

\section{APÊNDICE B - GRÁFICOS}

Com base na Entrevista constante do "Apêndice A", tendo sido compilados os dados, foram obtidos os seguintes resultados, todos com demonstrações gráficas a seguir:

Gráfico 01:

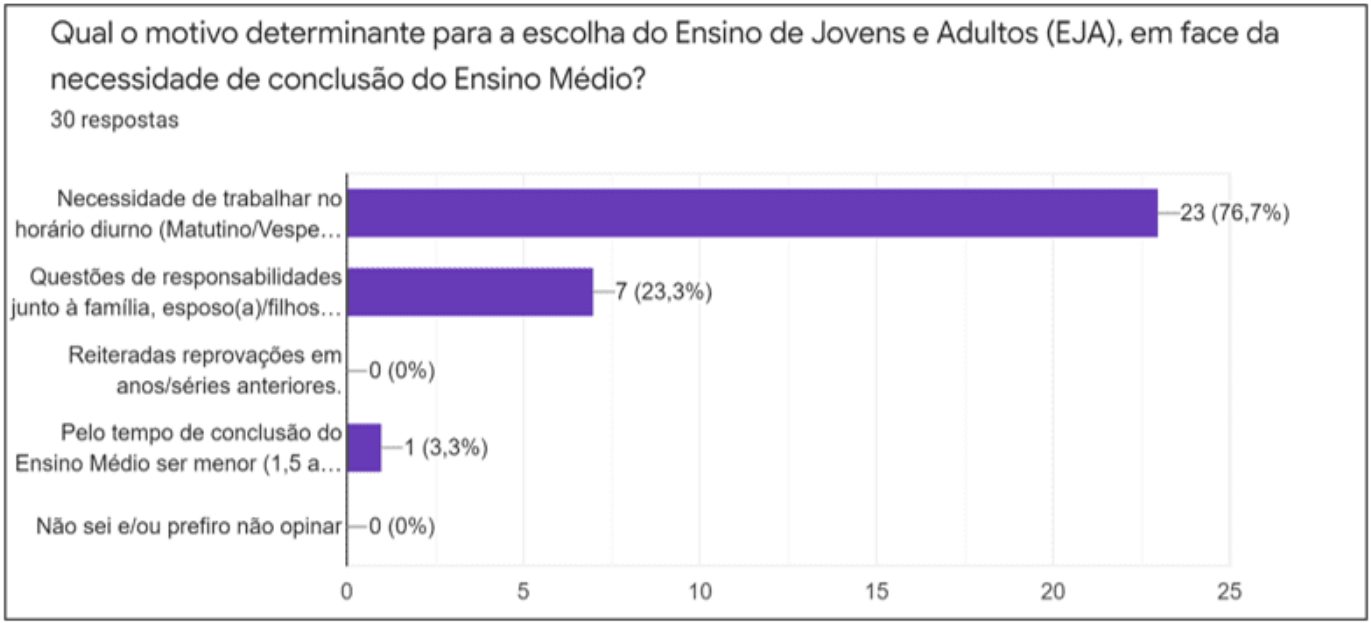

RC: 89981

Disponível em: https://www.nucleodoconhecimento.com.br/educacao/ensino-noestado 
Gráfico 02:

Que importância o Ensino Superior tem para seu futuro profissional? 30 respostas

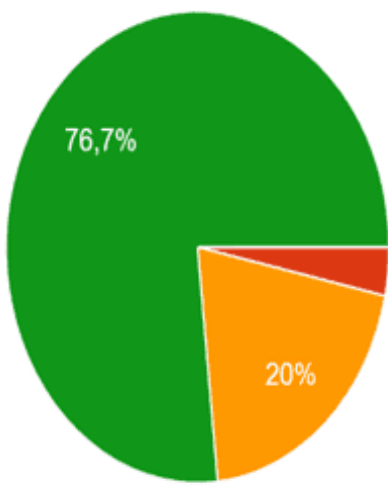

Pouco importante.

Importante

Muito importante

Extremamente importante

Não sei e/ou prefiro não opinar

\section{Gráfico 03:}

Você acredita ser possivel um(a) ex-aluno(a) do EJA ser aprovado em processo seletivo de Vestibular e cursar uma Faculdade?

30 respostas

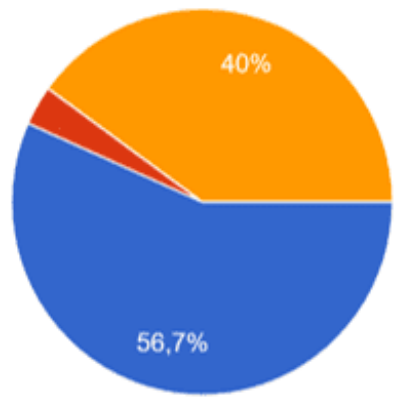

Acho ser possivel a aprovaçăo

Penso que seja dificil ser aprovado

Depende somente do ex-aluno do EJA

Não vê qualquer possibilidade

Não sei dizer e/ou prefiro năo opinar

RC: 89981

Disponível em: https://www.nucleodoconhecimento.com.br/educacao/ensino-no$\underline{\text { estado }}$ 


\section{Gráfico 04:}

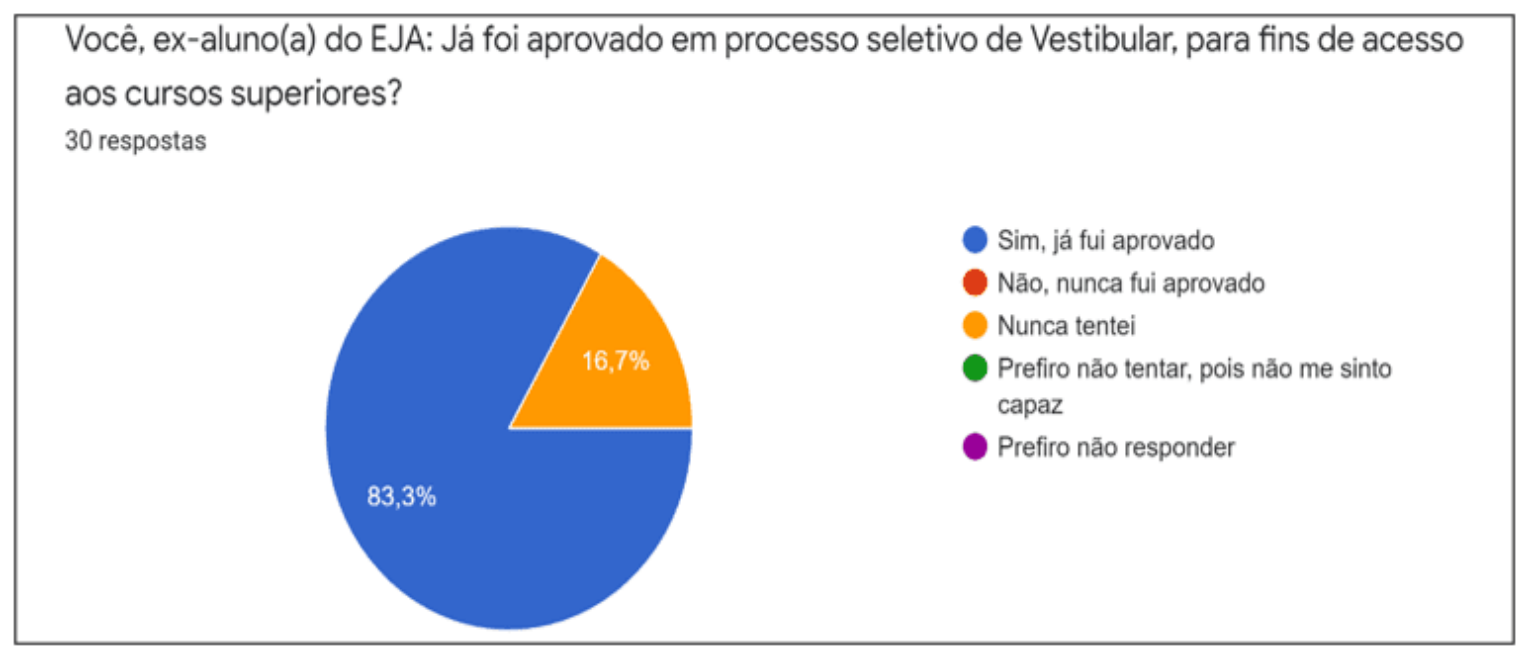

\section{Gráfico 05:}

Você, ex-aluno(a) do EJA: Já concluiu uma faculdade?

30 respostas

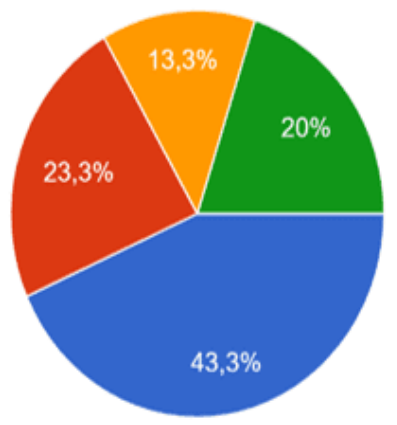

Sim, já conclui um curso superior

Não, não consegui concluir um curso superior

Já cursei alguns semestres, mas desanimei e abandonei os estudos

Estou cursando normalmente o ensino superior, com previsão de conclusão no período correto

Prefiro não opinar

RC: 89981

Disponível em: https://www.nucleodoconhecimento.com.br/educacao/ensino-noestado 
Gráfico 06:

Pretende fazer algum curso de pós-graduação ou está satisfeito com o ensino superior? 30 respostas

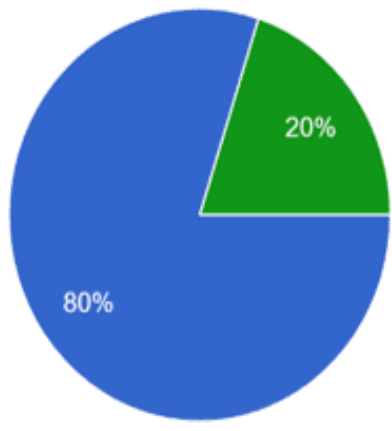

Pretendo continuar meus estudos

Não pretendo continuar

Se terminar a faculdade, já estarei satisfeito

Nunca cursei uma faculdade

Não me sinto capaz de continuar

\section{Gráfico 07:}

Já fez algum curso de pós-graduação, qual?

30 respostas

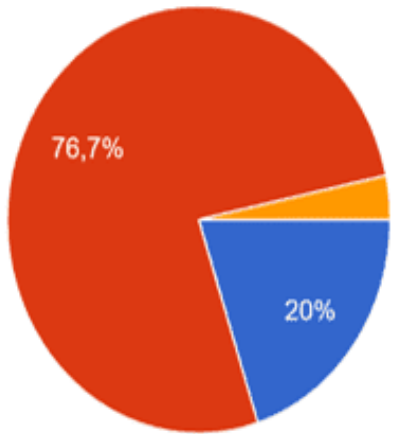

Sim, Especializaçăo Latu Sensu

Nunca cursei pós-graduação, mas pretendo começar em breve

Sim, Mestrado

Sim, Doutorado

Sou aluno de Mestrado ou Doutorado

RC: 89981

Disponível em: https://www.nucleodoconhecimento.com.br/educacao/ensino-noestado 


\section{APÊNDICE C - RELAÇÃO DOS ENTREVISTADOS}

\begin{tabular}{|l|}
\hline veronicadresch2@gmail.com \\
\hline ismaelmatos405@gmail.com \\
\hline araujosantoseva@gmail.com \\
\hline josenildopintodossantos@gmail.com \\
\hline eugenioludgerio@gmail.com \\
\hline emersonmatucari@gmail.com \\
\hline brunosdr1@gmail.com \\
\hline josiasatlevi@hotmail.com \\
\hline elis23oliveira@gmail.com \\
\hline rbuenoramalho@gmail.com.br \\
\hline ayronsilvaferreira@gmail.com \\
\hline wandersonwcp@gmail.com \\
\hline valdenilsaserrao@hotmail.com \\
\hline rodrigoteologo@hotmail.com \\
\hline
\end{tabular}

RC: 89981

Disponível em: https://www.nucleodoconhecimento.com.br/educacao/ensino-noestado 
ricbrito7@gmail.com

jeremias_trompetista@hotmail.com

oseiasojuara01@gmail.com

joaoricardo_rr_@hotmail.com

elieltonecs@hotmail.com

waynersmissoes@gmail.com

moabsampaio@hotmail.com

gabriiellycristine641@gmail.com

moises_s17@hotmail.com

diego.lopez@msn.com

arivaldo_ribeiro123@hotmail.com

galvaofs1@gmail.com

jesussoares.ieadrr@gmail.com

eldinosilva@gmail.com

RC: 89981

Disponível em: https://www.nucleodoconhecimento.com.br/educacao/ensino-noestado 
ssan_carioca@hotmail.com

roseamanha@hotmail.com

\section{APÊNDICE - REFERÊNCIA DE NOTA DE RODAPÉ}

2. Para maiores e melhores informações sobre a estatística apresentada, sugere-se a análise pormenorizada da matéria intitulada "Matrículas na educação de jovens e adultos caem; 3,3 milhões de estudantes na EJA em 2019", publicada pelo Instituto Nacional de Estudos e Pesquisas Estudantis Anísio Teixeira - INEP (MEC), disponibilizada no site do próprio INEP.

Enviado: Maio, 2021.

Aprovado: Junho, 2021. 